Eastern Illinois University

The Keep

Masters Theses

Student Theses \& Publications

Spring 2020

\title{
Financial Development in Developing Countries
}

Obinna Franklin Ezeibekwe

Eastern Illinois University

Follow this and additional works at: https://thekeep.eiu.edu/theses

Part of the Econometrics Commons, Finance Commons, and the Growth and Development Commons

\section{Recommended Citation}

Ezeibekwe, Obinna Franklin, "Financial Development in Developing Countries" (2020). Masters Theses. 4795.

https://thekeep.eiu.edu/theses/4795

This Dissertation/Thesis is brought to you for free and open access by the Student Theses \& Publications at The Keep. It has been accepted for inclusion in Masters Theses by an authorized administrator of The Keep. For more information, please contact tabruns@eiu.edu. 


\section{A Thesis}

on

\section{Financial Development in Developing Countries}

by

\section{Obinna Franklin Ezeibekwe}

Department of Economics

Eastern Illinois University

Charleston, IL, USA

Thesis Committee:

Dr. Ahmed Abou-Zaid

Dr. James Bruehler

Dr. Ali Moshtagh 


\section{TABLE OF CONTENTS}

ABSTRACT

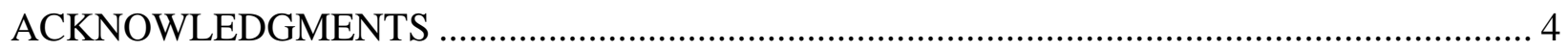

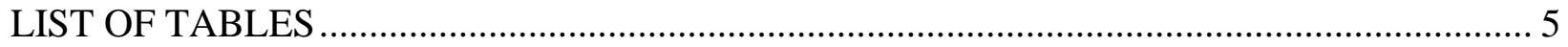

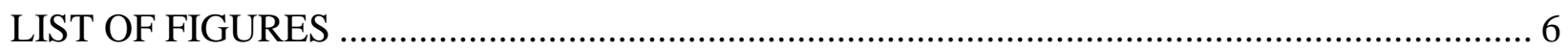

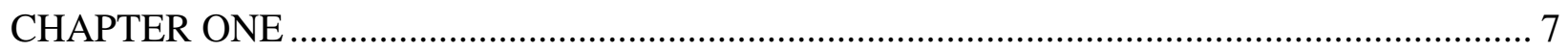

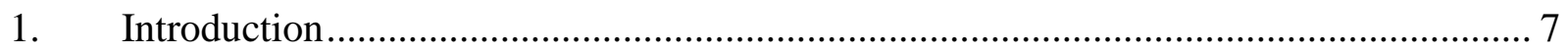

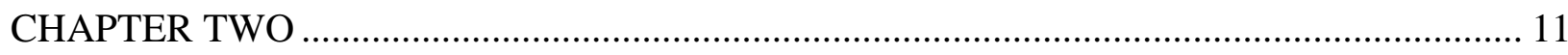

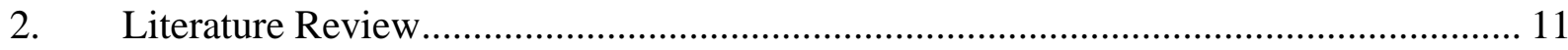

2.1. Financial Development, Economic Growth, Poverty, and Income Inequality ............. 14

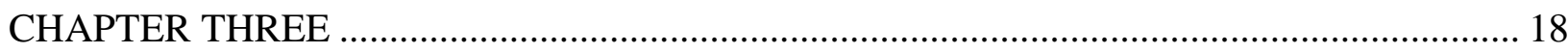

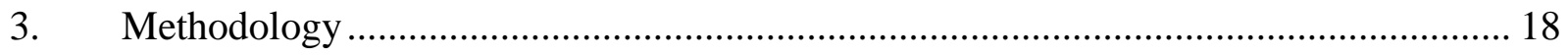

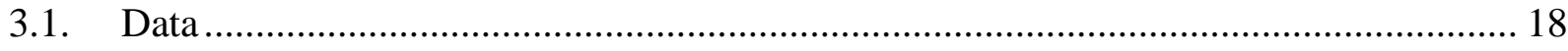

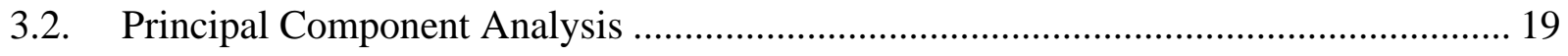

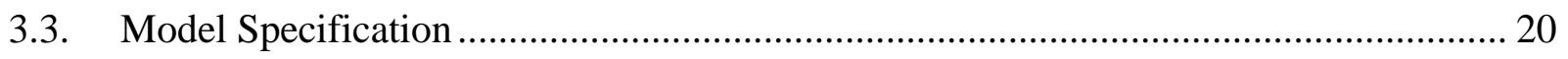

3.4. Potential Determinants of Financial Development in Developing Countries.............. 20

3.5. Econometric Methods and Issues................................................................... 22

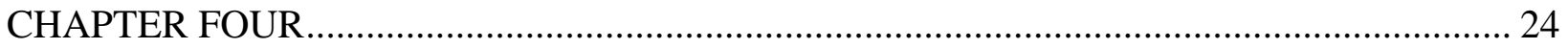

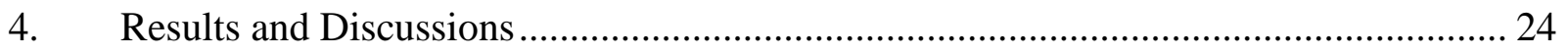

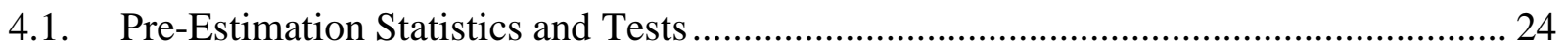




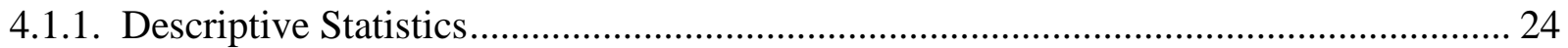

4.1.2. Descriptive Statistics with Bar Charts ..................................................................... 25

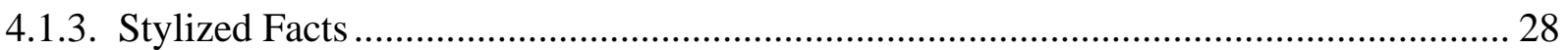

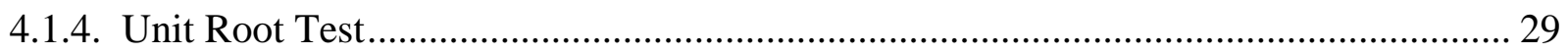

4.2 Discussion of Empirical Findings.......................................................................... 30

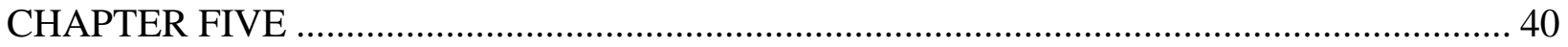

5. Conclusion and Recommendations .......................................................................... 40

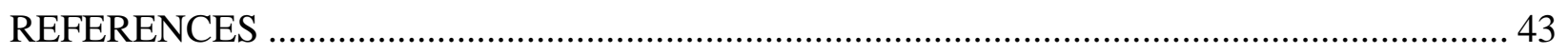

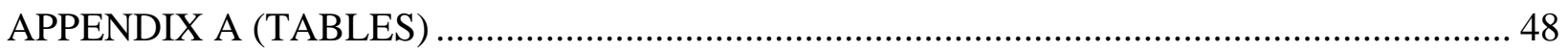

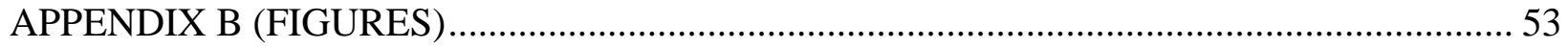




\begin{abstract}
What are the economic, political, institutional, socio-cultural, and geographical determinants of financial development in developing countries? This paper uses the two-way fixed effects (with clustered standard errors) and annual panel data from 1980 to 2018 for 69 developing countries in sub-Saharan Africa, Middle East and North Africa, East and South Asia, Latin America, and the Caribbean to address this question. The principal component analysis is employed to construct a financial development index based on three financial development indicators. This study builds on previous studies by introducing new potential determinants of financial development, such as the perception of corruption, and by exploring important quadratic and interaction effects. The results show that national income, trade openness, indices of political stability and Polity2 (a democracy score), perception of corruption, the predominant religion in the countries, and geographical factors such as territorial access to the sea explain the differences in the levels of financial development across countries and regions. A rise in national income leads to a higher level of financial development and countries with a high perceived level of corruption have a lower level of financial development. There is strong evidence of threshold effects as trade openness has a diminishing marginal effect on financial development while the auxiliary growth regressions show that financial development has an increasing marginal effect on national income. Of the five regions studied, East and South Asia and sub-Saharan Africa have the highest and lowest levels of financial development, respectively. Also, fuel-exporting countries, least developed countries, and landlocked countries tend to have lower levels of financial development. These results have relevant policy implications for developing countries in their continued efforts to achieve better financial development and ultimately, sustainable economic development.
\end{abstract}

Keywords: Financial development, developing countries, perception of corruption, principal component analysis, two-way fixed effects 


\begin{abstract}
ACKNOWLEDGMENTS
I am indebted to my exceptional parents for the determined effort and sacrifices they made to ensure that I attain this level of education. In addition, I thank my brothers and the entire Ezeibekwe family for their encouragement.

My profound appreciation to my thesis committee members, Drs. Ahmed Abou-Zaid, James Bruehler, and Ali Moshtagh, for their helpful comments. I would like to express my immense gratitude to my mentor, Emeritus Professor Mukti Upadhyay, for his advice and guidance. I salute the entire economics faculty members at EIU for the knowledge they impacted in me that helped me to complete this thesis. Special thanks to the staff of Booth library for making textbooks and journal articles available to me in a timely manner and to the economics librarian for assisting my research with respect to accessing economic data and top peer-reviewed journal articles. Above all, I thank God for His grace and mercy. Without God, I am nothing.
\end{abstract}




\section{LIST OF TABLES}

Table 1: List of the 69 Countries by Regions ............................................... 48

Table 2: Correlation Matrix of Financial Development Indicators ................................ 19

Table 3: Kaiser-Meyer-Olkin Measure of Sampling Adequacy Test ............................ 20

Table 4: Countries by other Classifications (United Nations, 2019) ............................... 49

Table 5: Countries by Perception of Corruption Index (Transparency International, 2018) ......... 50

Table 6: Countries by Religion (CIA World Factbook) ................................... 51

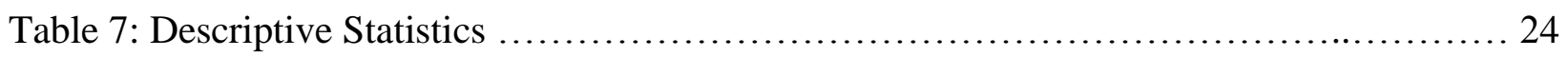

Table 8: Descriptive Statistics of Mean-Centered Variables Used in Regressions .................... 25

Table 9: Levin, Lin, and Chu (LLC) Unit Root Test at Levels .................................. 29

Table 10: Correlation Matrix of Trade Openness ...................................... 52

Table 11: Two-Way Fixed Effects Results (1980-2018) for 69 Countries ....................... 31

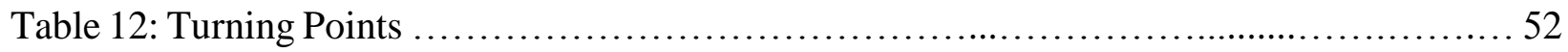

Table 13: Two-Way Fixed Effects Results (1980-2018) for 69 Countries with Regions ........... 35

Table 14: Growth Regressions for 69 Countries from 1980 to 2018 .......................... 38 


\section{LIST OF FIGURES}

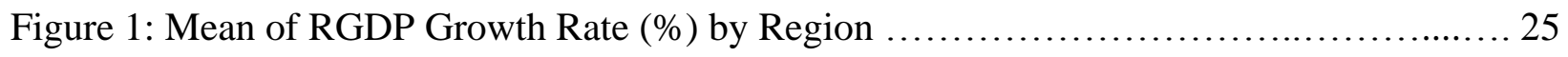

Figure 2: Mean of Composite Financial Development Index (FINANCE) by Region .......... 25

Figure 3: Mean of Broad money (\% of GDP) by Region .............................. 26

Figure 4: Mean of Domestic Credit to the Private Sector by Banks (\% of GDP) by Region ...... 26

Figure 5: Mean of Domestic Credit by Financial Sector (\% of GDP) by Region ............... 26

Figure 6: Mean of Trade Openness (\% of GDP) by Region ............................. 26

Figure 7: Mean of Index of Political Stability by Region ............................. 27

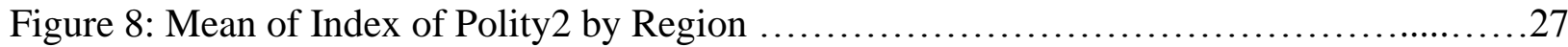

Figure 9: Mean of Inflation, GDP Deflator (Annual \%) by Region ..................... 27

Figure 10: Mean of RGDP Growth Rate (\%) by Perception of Corruption Index ............... 27

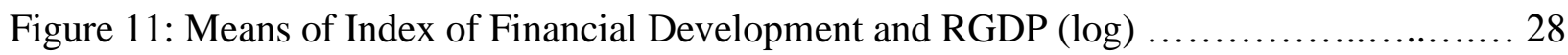

Figure 12: Means of Index of Financial Development and Trade Openness ................. 28

Figure 13: Means of Index of Financial Development and Inflation $\ldots \ldots \ldots \ldots \ldots \ldots \ldots \ldots \ldots \ldots . \ldots \ldots$

Figure 14: Means of Indices of Financial Development and Political Stability ............... 28

Figure 15: Means of Indices of Financial Development and Polity2 ..................... 53

Figure 16: Graph of Trade Openness (Quadratic) .................................. 53

Figure 17: Graph of Political Stability (Quadratic) ................................. 54

Figure 18: Graph of Polity2 (Quadratic) ........................................... 54

Figure 19: Graph of Index of Financial Development (Quadratic) .......................... 55 


\section{CHAPTER ONE}

\section{Introduction}

The theory that financial institutions and markets contribute significantly to economic growth and development by mobilizing funds from savers and channeling them to different sectors of the economy, to stimulate aggregate investment, employment, and output, has been proven. This idea was promulgated by earlier researchers such as Patrick (1966), Goldsmith (1969), Shaw (1973), and McKinnon (1973) and it has received the support of contemporary empirical results by Beck and Levine (2004), Jeanneney and Kpodar (2011), Kim and Lin (2011), and others. However, the diverse factors that engender financial development are not very well understood (Huang, 2010; Voghouei et al., 2011). This is what this study seeks to improve. The results of this study will improve our understanding of the determinants of financial development in developing countries and improve the knowledge of policymakers on how to build and/or develop financial institutions and markets that can play critical economic development roles.

Financial development entails an improvement in functions such as easing savings mobilization and expanding the production possibilities of an economy; allocation of funds to finance investments; enhancing the exchange of goods and services; stimulating the trading, diversification, pooling, and hedging of risks thereby reducing transaction costs; and monitoring managers and ensuring that the firms are managed in the best interest of the owners after financing the firms thereby reducing moral hazard (Levine, 1997). Past studies agree that financial development is a function of diverse factors from economic to geographical. For example, Huang (2010) asserts that financial development depends on various socio-economic, cultural, and geographical factors such as income level, inflation rate, political stability, ethnic and religious 
fragmentation, copyright protection, professional accounting practices, a country's territorial access to the sea and other factors.

A United Nations' World Economic Situation and Prospects 2018 report identified four key areas that policymakers must achieve to ensure the realization of the 2030 Agenda for Sustainable Development, ${ }^{1}$ the Addis Ababa Action Agenda, ${ }^{2}$ and other frameworks. ${ }^{3}$ They are economic diversification in monocultural economies that depend heavily on the exportation of one or few natural resources, reducing income inequality, establishing a strong financial architecture which is crucial to actualizing balanced and sustainable growth because it ensures a steady provision of finance for industrialization, and building robust institutional framework and security. Given the crucial role that financial development can play in alleviating poverty and hunger, promoting peace and security, promoting environmental protection (Saidi and Mbarek, 2016), discouraging tax evasion (Ahamed, 2016), serving as the link between foreign direct investment and growth in domestic entrepreneurship (Munemo, 2017), and ensuring that all persons have fulfilling lives through socio-economic and technological progress, it becomes necessary to identify the determinants of financial development in developing countries. Also, the negative impacts of financial crises such as the 2007 global financial crisis ${ }^{4}$ and the 1997 Asian financial crisis further underline the significance of this study.

Against this backdrop, the main objective of this research is to identify the economic, political, institutional, social-cultural, and geographical factors that influence the financial development of 69 developing countries, based on United Nations 2019 classification (see

\footnotetext{
${ }^{1}$ See Transforming our World: The 2030 Agenda for Sustainable Development, 2015

${ }^{2}$ See Addis Ababa Action Agenda: Financing for Development, 2015

${ }^{3}$ Includes Future We Want, 2012; Sendai Framework for Disaster Risk Reduction, 2015; SAMOA Pathway, 2014

${ }^{4}$ See Temin (2010) for more discussion.
} 
Appendix A, Table 1) from 1980 to 2018. In addition, this study explores the quadratic and interaction effects of the potential determinants. This paper also re-examines the notion that financial development contributes significantly to the economic growth of these countries.

This paper will empirically answer the following questions. What are the determinants of financial development in developing countries? Do the potential determinants have important quadratic and interaction effects on financial development? Which developing region has the highest level of financial development? Finally, Is financial development important to the economic growth of developing countries? This research employs different econometric methods to address the questions posed by this study. First, I construct a composite financial development indicator using the principal component analysis (PCA) and applied the Kaiser-Meyer-Olkin sampling adequacy test to determine if the three financial development indicators are related enough to warrant the application of principal component analysis. Then, a unit root test is conducted on the variables to determine whether they are stationary or non-stationary and the Sargan-Hansen robust test is used to determine the appropriate model for the data. The models are estimated using the Least Squares Dummy Variable (LSDV) method while controlling for entity and time fixed effects and using clustered standard errors.

This study finds that economic, political, institutional, geographical, and socio-cultural factors account for the differences in the levels of financial development across countries and regions. Specifically, national income, trade openness, indices of Polity2 and political stability, corruption levels, territorial disadvantages, and religious composition of the country are important determinants of the variations in the financial development of developing countries. First, national income is a positive and relevant determinant of financial development. The most interesting finding of this paper is in the non-linearities of the determinants. Trade openness has a diminishing 
marginal effect on financial development only when trade openness reaches 354.85 percent of GDP. Most developing countries are well-below this threshold.

Similarly, the indices of political stability and Polity2 show significant non-linearities. The curves of the indices of political stability and Polity 2 are U-shaped, suggesting that political stability and Polity2 contribute positively to financial development when the scores of 24 and 3 are reached, respectively. Furthermore, countries with high and medium perceived levels of corruption have a lower level of financial development than countries with low perceived levels of corruption. Political and institutional factors have a direct and indirect effect on financial development and can seriously undermine the supply of credit. This underlines the importance of robust institutions if a country wants to achieve a strong financial system. Across the regions, the East and South Asia region has the highest level of financial development while sub-Saharan Africa has the lowest level of financial development in the world. In addition, fuel-exporting countries, least developed counties, and landlocked countries have relatively lower levels of financial development. Socio-cultural factors indirectly determine a country's level of financial development as religious affiliation affects a society's competitiveness and institutional quality.

The remainder of the paper is organized as follows. Chapter 2 reviews the results of past research on the determinants of financial development and a sub-chapter presents empirical evidence that shows that financial development is positively associated with sustainable development by reducing poverty and income inequality. Chapter 3 presents the methodology of the research and it includes the data, principal component analysis, model specification, potential determinants of financial development, and econometric methods and issues. Results and discussions, including pre-estimation statistics and model estimations, are reported in chapter 4 . A final chapter gives the conclusion and policy recommendations. 


\section{CHAPTER TWO}

\section{Literature Review}

The positive association between financial development and economic growth and the roles financial development play in reducing poverty and income inequality has motivated several studies to investigate the determinants of financial development in developing and emerging economies. This section presents the results of some of those studies.

Huang (2005) investigates the determinants of financial development using a joint application of the Bayesian Model Averaging and the General-to-Specific methods. The results suggest that initial income, trade openness, initial population, institutional quality, government policies, geographic factors, cultural features (like religion and ethnic diversity indirectly) affect a country's level of financial development. Similarly, Baltagi et al. (2007) study the causes of variation in financial development across countries and over time. The main finding is that robust economic institutional framework and trade openness are important determinants of financial development.

Using data from 1990 to 2007 for 14 countries in the Middle East and North Africa, Cherif and Gazdar (2010) examine the determinants of equity market development. The findings show that national income, stock market liquidity, interest rate, and savings rate determine the level of stock market development while the inflation rate is not an important factor. Chinn and Ito (2005) analyze the impact of capital account liberalization, legal, and institutional development on financial development, with emphasis on equity markets, using data for 108 countries from 1980 to 2010. They find that financial liberalization leads to financial development when a certain level of institutional and legal quality has been attained. 
Furthermore, Herger et al. (2008) study how institutions, trade, and culture explain the differences in the levels of financial development across countries. Institutions that enforce the rule of law and trade openness have a positive and direct impact on financial development while religion has an indirect effect on financial development through institutions. Boyd et al. (2000) investigate the ability of the inflation rate to affect the allocative function of the financial sector. The result shows a non-linear and negative correlation between the financial sector's ability to allocate resources and inflation and the size of the magnitude is both economically and statistically meaningful. Also, there is a significant drop in the performance of the financial system when the inflation rate is above 15 percent.

In addition, Roe and Siegel (2011) determine that political instability is negatively associated with financial development and it is relevant for explaining the different levels of financial development around the world. In a study of the socio-economic determinants of financial development for 57 developing countries, Outreville (1999) finds that financial development is directly and inversely correlated with human capital development and political instability, respectively. Human capital development is relevant for financial development because a more educated populace is less risk-averse, has more savings, and has more access to information. In addition, income per capita is an important determinant of financial development while the real interest rate and inflation rate are not relevant.

Using data covering the period of 1870 to 1940 and 1970 to 2005 for 31 and 133 countries respectively, Bhattacharyya and Hodler (2011) examine whether resource-rich countries have a higher level of financial development. The result shows that resource-rent are negatively correlated with financial development in countries with lower levels of democratization. Another factor that engenders financial development is World Bank lending. Cull and Effron (2008) investigate 
whether countries that received World Bank loans from 1992 to 2003, with its financial reforms, performed better in financial development indicators than countries that did not receive these loans. The result postulates that, generally, countries that received the loans showed more prospects in financial development than countries that did not.

Studying the effects of private remittances on poverty and the financial development of 24 sub-Saharan African countries, Gupta et al. (2009) find that private remittances reduce poverty and promote financial development in these countries. Equally, Karikari et al. (2016) examine the association between remittances and financial development in Africa. Using data for 50 countries from 1990 to 2011, the result indicates that remittances encourage financial development. As a result, a higher level of financial development encourages more remittances. Remittances increase the amount of credit available to the economy for investment and consumption.

Some studies specifically investigated the determinants of financial inclusion (the extension of banking sector facilities and services to the unbanked and underbanked households and firms) in developing countries. Datta and Singh (2019) investigate the determinants of financial inclusion using data for 102 developed and developing countries. They find that there is a direct correlation between financial inclusion and the level of human development. Specifically, improvements in income, education, and health outcomes improve people's awareness and ability to demand financial facilities and services. Similarly, Leon and Zins (2020) find that the presence of Pan-African banks enhances firms' ability to acquire credit thereby encouraging financial inclusion in Africa.

Social trust also plays an important role in financial inclusion. Using data for 148 countries, $\mathrm{Xu}$ (2019) shows that social trust is a significant contributor to financial inclusion. When social 
trust is high, the use of banking services such as savings facilities and borrowing increases. Social trust also encourages participation in the financial market in the presence of imperfect information. Another vital factor that stimulates financial development is financial literacy, the set of knowledge and acumen that empowers households and firms to make optimal decisions as to how to allocate and utilize available financial resources and services. Karakurum-Ozdemir et al. (2019) study the determinants of financial literacy in developing countries. The result shows that financial literacy is determined by personal income, gender, educational level, and linguistic factors. Specifically, higher income leads to higher financial literacy, men have higher financial literacy scores than women, individuals with tertiary education have higher financial literacy, and not being fluent in the official (common) language leads to lower financial literacy.

\subsection{Financial Development, Economic Growth, Poverty, and Income Inequality}

Various studies have shown that financial development improves sustainable economic development and reduces poverty and the income gap in developing countries. This sub-chapter presents the results of such studies.

Studying a broad cross-section of 80 countries using data averaged over 1960-1989, King and Levine (1993) show that the financial system positively impacts the economic growth of all economies. Specifically, financial development indicators are positively associated with economic efficiency improvement, physical capital accumulation, and RGDP per capita growth. Also, Christopoulos and Tsiona (2004) examine the long-run relationship between financial depth and economic growth of 10 developing countries. The empirical results support the view that financial depth is a positive contributor to economic growth, and that there is unidirectional causality from financial depth to economic growth. 
Similarly, Hassan et al. (2011) investigate the role of financial development in the economic growth of low- and middle-income countries. The results show a strong positive relationship between financial development and economic growth in developing countries. Also, the short-term result shows a bidirectional causality between financial development and economic growth for most regions and unidirectional causality from economic growth to financial development for sub-Saharan African countries and East Asia and the Pacific. Furthermore, Asghar and Hussain (2014) estimate the association between financial development and economic growth in developing countries from 1978 to 2012. According to the findings, there is strong evidence that financial development contributes to long-run economic growth in developing countries.

Using data for 40 countries to determine the effects of stock and credit markets on the income per capita, Durusu-Ciftci et al. (2017) state that both markets contribute positively to increases in income per capita in the long run. As a result, more efforts should be made to develop the financial system. Additionally, Calderon and Liu (2003) examine the causal relationship between financial development and economic growth using data for 109 developed and developing countries. They find that financial development causes economic growth and that there is a bidirectional relation between financial development and economic growth. Likewise, Bangake and Eggoh (2011) find a bidirectional relationship between financial development and growth for a panel of 71 developed and developing countries from 1960 to 2004.

Income inequality unfavorably affects the ability of the poor to access productive resources which leads to economic inefficiency because the productive capabilities of the poorer people are underutilized (Ferreira, 1999). Therefore, the higher the percentage of poor people in a country, the lower the rate of economic growth. Examining the impact of financial development on poverty 
and income inequality of 78 developing and developed countries from 1960 to 2006 and using panel regression and cross-country regression, Kappel (2010) finds that financial development significantly reduces poverty and income inequality. Also, the impact of financial development on poverty is larger than the impact on inequality. Similarly, financial inclusion is an important tool for reducing income inequality (Park and Shin, 2017).

In the same vein, Jeanneney and Kpodar (2011) analyze how financial sector development affects poverty reduction in developing countries from 1966 to 2000 . They find that financial development benefits the poor by empowering them to acquire liquid assets and receive a higher savings rate but costs them through financial crises which affect the poor more. In general, the positive effect of financial development outweighs the costs. Kim and Lin (2011) elucubrate the impact of financial development on income inequality for a sample of developed and developing economies from 1960 to 2005 . The result proves that financial development reduces income inequality after a threshold; before this threshold, financial development is detrimental to income inequality. Law et al. (2014) examine whether the relationship between financial development and income inequality depends on the quality of the institutional framework for 81 countries for the period 1985 to 2010. They find that countries must attain a certain level of institutional quality for financial development to significantly reduce income inequality; below this threshold, the impact of financial development on income inequality is negligible.

The bulk of the evidence shows that financial development plays key roles in improving economic growth, alleviating poverty, and reducing income inequality. However, these effects of financial development depend on factors such as a robust institutional framework, a higher level of financial development, and sound macroeconomic policies. Empirical evidence points to the fact that financial development is determined by a variety of factors ranging from economic to 
cultural. This paper builds on previous research by introducing new potential determinants of financial development, such as the perceived level of corruption, and exploring the quadratic and interaction effects of the potential determinants.

To achieve the objectives of this paper, the study builds a model that expresses a composite financial development indicator in terms of relevant economic, political, institutional, socialcultural, and geographical determinants. The composite financial development indicator was constructed using three financial development indicators popular in the finance literature and they are broad money (liquid liabilities) as a percent of GDP (M3/GDP), domestic credit to the private sector by banks as a percent of GDP, and domestic credit provided by the financial sector as a percent of GDP. Previous empirical works (such as Raza et al., 2014) used one or two indicators to proxy financial development. In this paper, I employ three key financial development indicators relevant to developing countries to construct a composite index of financial development because a single indicator is not capable of explaining financial development which affects an economy through different channels. Unlike previous studies that used data averaged over a certain period, I use a more recent yearly dataset (from 1980 to 2018) which captures the variations in the data in a way averaged data do not and to provide new evidence. 


\section{CHAPTER THREE}

\section{Methodology}

\subsection{Data}

This study employs annual panel data for 69 developing economies over the period of 1980 to 2018, a period of 39 years. This paper uses a large panel dataset with each variable containing about 2691 observations. This entails the collection of about 67,275 observations for the 25 variables used in the study. The sources of the data are discussed in sub-chapter 3.4.

To construct the composite financial development indicator, I use data from World Bank's World Development Indicators for the following financial development indicators: broad money (or liquid liabilities) as a percent of GDP, domestic credit to the private sector by banks as a percent of GDP, and domestic credit provided by the financial sector as a percent of GDP. ${ }^{5}$ Broad money (M3) as a percent of GDP is the most comprehensive measure of money supply in an economy. Domestic credit to the private sector by money deposit banks as a percent of GDP measures the lending capabilities of banking institutions in an economy and it includes loans, overdrafts, trade credits, purchases of non-equity securities like bonds and options, and other accounts receivable that are to be repaid. This is important in an economy because it finances investment, production, distribution, and consumption of goods and services. Domestic credit provided by the financial sector as a percent of $\mathrm{GDP}^{6}$ measures financial sector development in terms of size.

\footnotetext{
${ }^{5}$ Due to data insufficiency, I excluded equity market development indicators such as stock market capitalization as a percent of GDP and stock market turnover ratio. Besides, most developing countries do not have well-developed equity markets and the financial development index used in this study represents a decent measure of financial development in developing countries. The arguments that developing countries have not reached the development stage (Goldsmith, 1969) and/or do not have the institutions (Herger et al., 2008) necessary for the proper functioning of stock markets gives more credence to the adequacy of the financial development index used in this study.

${ }^{6}$ Domestic credit provided by the financial sector consists of all gross credit to different sectors of an economy and net credit to the central government. The financial sector includes monetary authorities and deposit money banks, as
} 


\subsection{Principal Component Analysis}

I employ the principal component analysis (PCA) to construct the composite index of financial development used in this study. ${ }^{7}$ I use the first principal component which accounts for the highest amount of variations in the original three financial development indicators. The principal component analysis requires that the financial development indicators be interrelated and correlated. The result shows that the variables are correlated with 0.8625 and 0.7547 being the highest and lowest correlation coefficients, respectively. The result of the correlation matrix is presented in Table 2.

Table 2: Correlation Matrix of Financial Development Indicators

\begin{tabular}{|l|c|c|c|}
\hline VARIABLE & Broad Money & Bank Credit & $\begin{array}{c}\text { Financial } \\
\text { Sector Credit }\end{array}$ \\
\hline Broad Money & 1.0000 & - & - \\
\hline Bank Credit & 0.8625 & 1.0000 & - \\
\hline Financial Sector Credit & 0.8003 & 0.7547 & 1.0000 \\
\hline
\end{tabular}

Source: Author's computation (2020)

I employ the Kaiser-Meyer-Olkin sampling adequacy test to determine if the three financial development indicators are interrelated enough to justify the application of principal component analysis (Kaiser, 1974; Cerny and Kaiser, 1977).

Since the KMO statistic is greater than 0.5 , I conclude that the financial development indicators are interrelated enough to justify the use of PCA. The result of the KMO sampling adequacy test is presented in Table 3 .

well as other financial corporations where data are available (including corporations that do not accept transferable deposits but are liable to time and savings deposits). Examples of other financial corporations are insurance corporations, finance and leasing companies, pension funds, money lenders, and foreign exchange companies.

7 The principal component analysis reduces the dimensionality of a data set consisting of interrelated variables, while retaining the majority of the variation present in the data set. See (OECD, 2008) for more discussion. 
Table 3: Kaiser-Meyer-Olkin Measure of Sampling Adequacy Test

\begin{tabular}{|l|c|}
\hline VARIABLE & KMO \\
\hline Broad Money & 0.6857 \\
\hline Bank Credit & 0.7336 \\
\hline Financial Sector Credit & 0.8302 \\
\hline OVERALL & $\mathbf{0 . 7 4 2 0}$ \\
\hline
\end{tabular}

Source: Author's computation (2020)

\subsection{Model Specification}

This work is based on the works of Huang (2005), Herger et al. (2008), and Baltagi et al. (2009). I follow these studies to express financial development in terms of several potential determinants. However, I control for variables not included in these studies and explored quadratic and interaction effects. I specify the panel data model of this study in general and compact form as:

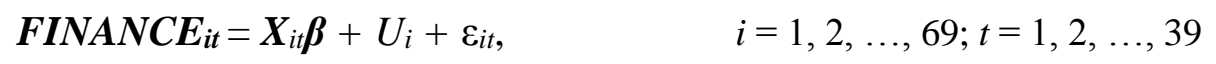

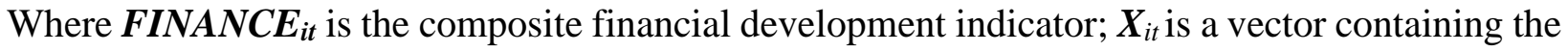
potential determinants of financial development and $\boldsymbol{\beta}$ is a vector containing the estimated coefficients of the variables contained in $\boldsymbol{X}_{i t} . U_{i}$ is the unobserved effects, and $\varepsilon_{i t}$ is the idiosyncratic error.

\subsection{Potential Determinants of Financial Development in Developing Countries}

The economic literature on the determinants of financial development has identified important economic, political, institutional, geographical, and social-cultural factors that determine financial development.

The economic determinants used in this study include the log of real gross domestic product (2010 constant dollars) which measures the level of national income, trade openness as a 
percent of GDP (calculated as the sum of export and import divided by GDP) which measures the importance of international trade to an economy and inflation rate (GDP deflator) which measures the rate of price changes in the whole country. The data for these variables were collected from World Bank's World Development Indicators, Federal Reserve Economic Data (FRED) sourced from the Federal Reserve Bank of St. Louis, and Global Economy. I include binary variables for fuel-exporting countries and least developed countries based on United Nations 2019 Classification (see Appendix A, Table 4).

To control for political and institutional factors, this paper adopts an index of political stability (durable) and an index of Polity2 (a democracy score). Both were derived from the Polity IV project database compiled by the Center for Systemic Peace and Societal-Systems Research Inc. The index of political stability measures the number of years since the latest change of regime (a 3-point change over three years or less in the Polity score). The Polity2 is a score based on the competitiveness of executive recruitment, the openness of executive recruitment, chief executive constraints, and political participation competitiveness. It ranges from -10 to 10, with -10 and 10 indicating the strongest adherence to autocracy and democracy, respectively. In addition, I include a categorical variable for the perception of corruption because corruption (the improper use of public power and/or authority for selfish interests) can explain the institutional quality. The Transparency International 2018 Corruption Perception Index ranks 180 countries, with rank 1 being the least corrupt and rank 180 being the most corrupt, based on their perceived levels of public sector corruption as determined by surveys and the assessments of experts. I divide the countries into three groups and classified countries ranked from 1 to 60 as low perception of corruption, countries ranked from 61 to 100 as medium perception of corruption, and countries ranked from 101 to 180 as high perception of corruption (see Appendix A, Table 5). 
I divide the 69 countries into five regions - namely sub-Saharan Africa, the Middle East and North Africa (MENA), Latin America, East and South Asia, and the Caribbean - to measure the levels of financial development across these regions. Another geographical variable used in the study is a binary variable for landlocked countries (see Appendix A, Table 4). The binary variable takes the value of 1 if the country has no territorial access to the sea. The geographical determinant, landlocked, has an indirect impact on financial development. The idea is that the lack of territorial access to the sea hinders external trade, economic growth, and consequently financial development.

Several studies, such as Stulz and Williamson (2003) and others, argue that religious affiliation shapes a society's view on competition, property rights, and the role of the government. Therefore, religious composition can explain the differences in the level of investor protection and institutional quality. I follow Beck et al. (2003), Herger et al. (2008), and others to include religious affiliation as an indirect determinant of financial development. For the socio-cultural variables, I use information from the Central Intelligence Agency (CIA) World Factbook to categorize countries into three religious groups: Christian, Muslim, and Others. To belong to either the Christian or Muslim group, a country must have at least 51 percent of its population identify as either Christian or Muslim. Countries that fail to meet this criterion are classified as Others (see Appendix A, Table 6).

\subsection{Econometric Methods and Issues}

First, this paper uses the principal component analysis (PCA) to construct the composite financial indicator used in this study, and the Kaiser-Meyer-Olkin sampling adequacy test justifies the suitability of the three financial development indicators for principal component analysis. This study employs pre-estimation analyses such as descriptive statistics, descriptive statistics with bar 
charts, stylized facts, and the Levin, Lin, and Chu unit root test. The Levin, Lin, and Chu unit root test is applied to find out if the variables are stationary or non-stationary. To select the appropriate estimation method for the data, I employ the robust Sargan-Hansen test which suggests that fixed effects methods is best for the equations.

The model of this study expresses an index of financial development in terms of its potential determinants. The first potential factor is the real gross domestic product $(\log )$ which induces simultaneity bias because financial development causes economic growth. To control for the bias, I use the lag of RGDP in the model. I employ the Least Squares Dummy Variable (LSDV) method, which controls for omitted variable bias and produces the same coefficients and standard errors as the fixed effects (within) estimator, to estimate the equations. The choice of LSDV is because of its ability to estimate binary variables. I use the full set of entity and time fixed effects and clustered standard errors that control for autocorrelation and heteroscedasticity in all the equations.

Some right-hand side variables are expressed as squared or interaction terms. The problem with these transformations is that they increase the correlation coefficients of the variables involved thereby inducing multicollinearity. I use the grand mean-centered form of the continuous variables to control for the multicollinearity. The last issue is that of missing data of financial development indicators used to construct the index of financial development. Broad money, bank credit, and financial sector credit (all as a percent of GDP) have 17, 16, and 22 missing values respectively, which account for $0.6317,0.5946$, and 0.8175 percent respectively. The missing values were imputed using mean/median imputation where appropriate. This technique does not bias the estimates since the missing values are less than 2 percent (see OECD, 2008; Enders, 2010). 


\section{CHAPTER FOUR}

\section{Results and Discussions}

This chapter is divided into two broad sections: pre-estimation statistics and discussion of empirical findings.

\subsection{Pre-Estimation Statistics and Tests}

\subsubsection{Descriptive Statistics}

Table 7 presents the descriptive statistics for the non-categorical variables and the descriptive statistics of mean-centered variables are presented in Table 8. Evidently, the total number of observations is 2691. The indices of financial development, Polity2, political stability, and inflation rate have no missing observation. However, $\mathrm{RGDP}_{\mathrm{t}-1}(\log )$ has 2622 observations because each country lost one observation because of the lag. Trade openness and the net inflow of foreign direct investment have 8 missing values each. The large standard deviation (425) of the inflation rate compared to the mean of 38 is due to the high level of inflation rate in Latin America.

Table 7: Descriptive Statistics

Sample: 1980-2018

\begin{tabular}{|c|c|c|c|c|c|c|c|}
\hline & Index of Finance & $\operatorname{RGDP}_{\mathrm{t}-1}(\log )$ & $\begin{array}{c}\text { Trade } \\
(\% \text { of GDP) }\end{array}$ & $\begin{array}{l}\text { FDI, Net Inflow } \\
\text { (\% of GDP) }\end{array}$ & Inflation & $\begin{array}{l}\text { Index of } \\
\text { Polity } 2\end{array}$ & $\begin{array}{c}\text { Index of Political } \\
\text { Stability }\end{array}$ \\
\hline Mean & $-6.39 \mathrm{E}-09$ & 24.07163 & 71.60666 & 2.469959 & 38.65402 & 1.873653 & 18.32256 \\
\hline Median & -0.479153 & 23.76438 & 60.35732 & 1.476619 & 6.916061 & 5.000000 & 13.00000 \\
\hline Maximum & 8.540589 & 29.94671 & 437.3267 & 50.63641 & 13611.63 & 10.00000 & 99.00000 \\
\hline Minimum & -2.699460 & 20.13713 & 6.320343 & -55.23406 & -29.69107 & -10.00000 & 0.000000 \\
\hline Std. Dev. & 1.616325 & 1.880728 & 48.50653 & 4.220458 & 425.3020 & 6.581461 & 18.14944 \\
\hline Observations & 2691 & 2622 & 2683 & 2683 & 2691 & 2691 & 2691 \\
\hline
\end{tabular}

Source: Author's computation (2020) 
Table 8: Descriptive Statistics of Grand Mean-Centered Variables Used in Regressions

\begin{tabular}{lcccc}
\hline \hline & RGDP $_{\mathrm{t}-1}(\mathrm{log})$ & Trade Openness & FDI, Net Inflow & Inflation \\
\hline \hline Mean & 0.428198 & $3.03 \mathrm{E}-07$ & $5.07 \mathrm{E}-09$ & $1.24 \mathrm{E}-06$ \\
Median & 0.120947 & -11.24934 & -0.993340 & -31.73796 \\
Maximum & 6.303279 & 365.7201 & 48.16645 & 13572.98 \\
Minimum & -3.506297 & -65.28632 & -57.70402 & -68.34509 \\
Std. Dev. & 1.880728 & 48.50653 & 4.220458 & 425.3020 \\
Observations & 2622 & 2683 & 2683 & 2691
\end{tabular}

\subsubsection{Descriptive Statistics with Bar Charts}

This sub-section presents bar charts that compare the means of selected variables in descending order for the 69 developing countries studied across regions from 1980 to 2018. Figure 1 shows the means of RGDP growth rates of the regions studied. For the period under review, the East and South Asia region recorded the highest RGDP growth rate of 5.2 percent while the Caribbean region has the lowest at 2 percent.

Figure 1: Mean of RGDP Growth Rate (\%) by REGION Figure 2: Mean of Composite Financial Development Index (FINANCE) by REGION
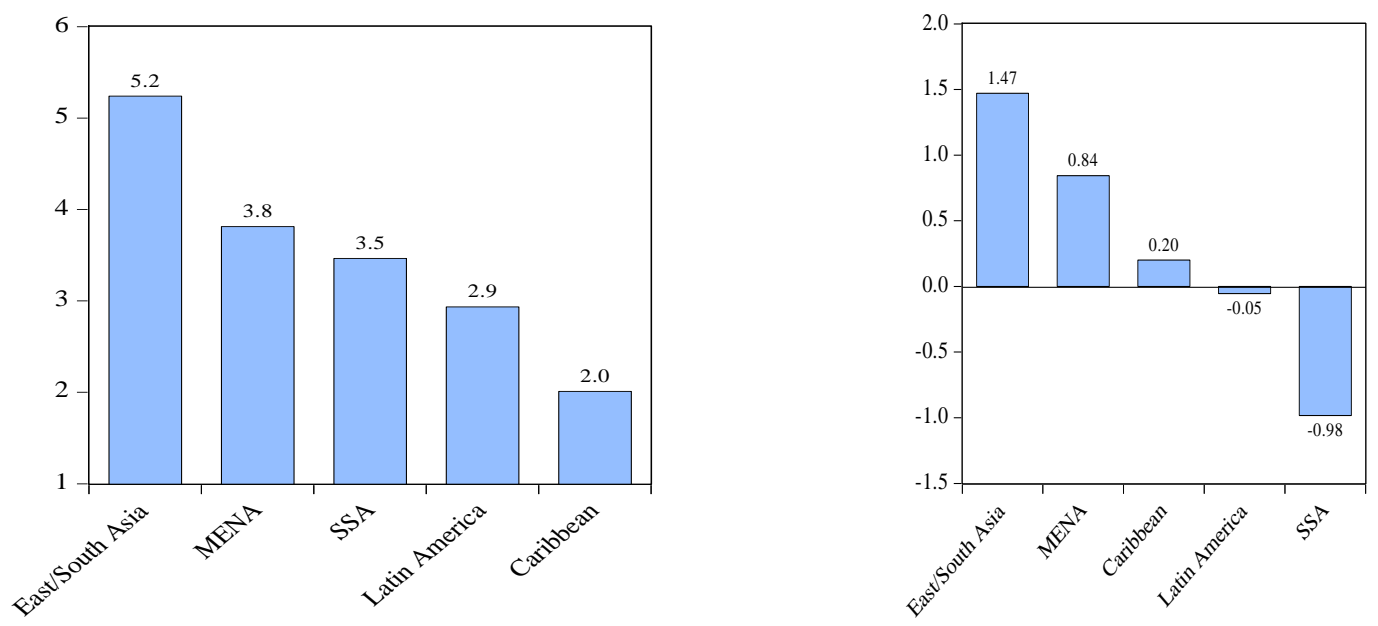

Similarly, East and South Asia region has the highest values for the index of financial development, broad money (as a percent of GDP), domestic credit to the private sector by banks (as a percent of GDP), and domestic credit provided by the financial sector (as a percent of GDP) and sub-Saharan Africa has the lowest values for all financial development indicators as shown in Figures 2, 3, 4, and 5 below. 
Figure 3: Mean of Broad Money (\% of GDP) by REGION

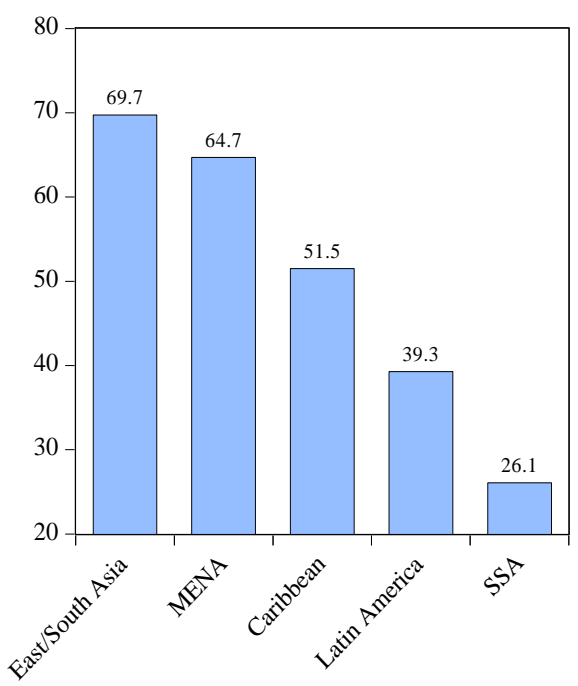

Figure 5: Mean of Domestic Credit by Financial Sector (\% of GDP) by REGION

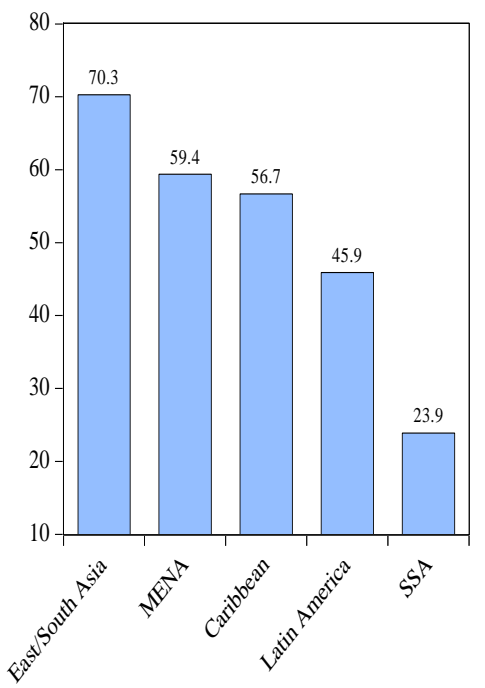

Figure 4: Mean of Domestic Credit to the Private Sector by Banks (\% of GDP) by REGION

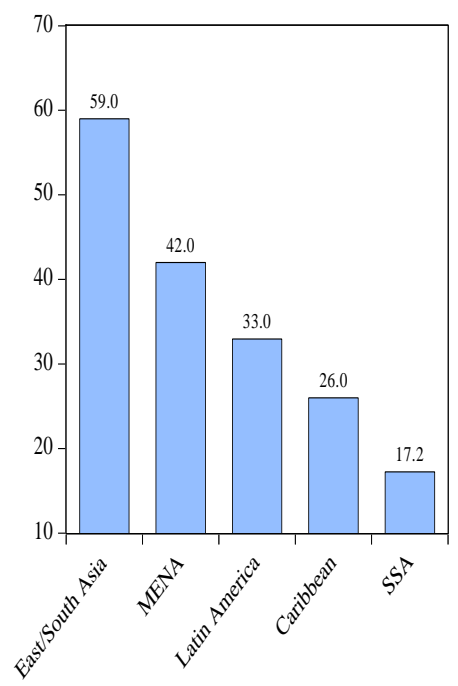

Figure 6: Mean of Trade Openness (\% of GDP) by REGION

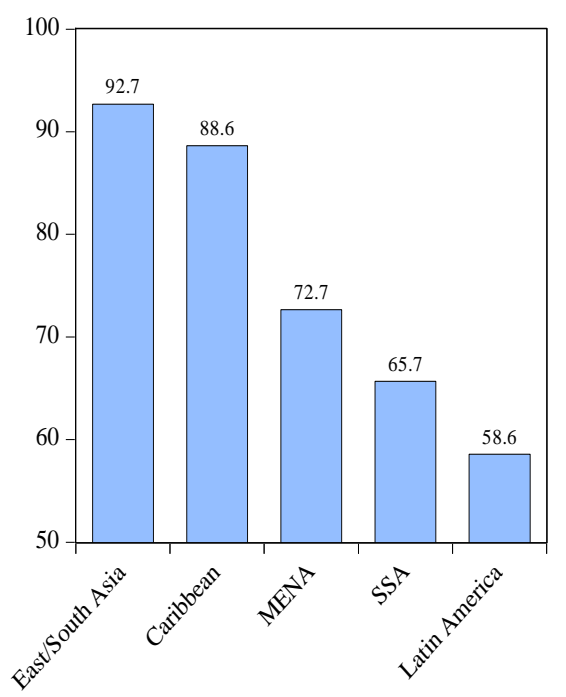

From Figure 6 above, East and South Asia recorded the highest value for trade openness. For the index of Political stability, the MENA region averaged 27.2 to rank as the highest while sub-Saharan African averaged 13.8 to rank as the lowest region. Latin American countries are the most democratic while MENA countries are the least democratic according to Polity2 (Figures 7 and 8 below). Lastly, Figures 9 and 10 below show that Latin American countries have the highest inflation rate over the period of 1980 to 2018 while East and South Asia recorded the lowest 
inflation rate and countries with a higher level of corruption (ranging from 101 to 180) have the lowest RGDP growth rate while countries with a lower level of corruption (ranging from 1 to 60) have the highest RGDP growth rate from 1980 to 2018.

Figure 7: Mean of Index of Political Stability by REGION

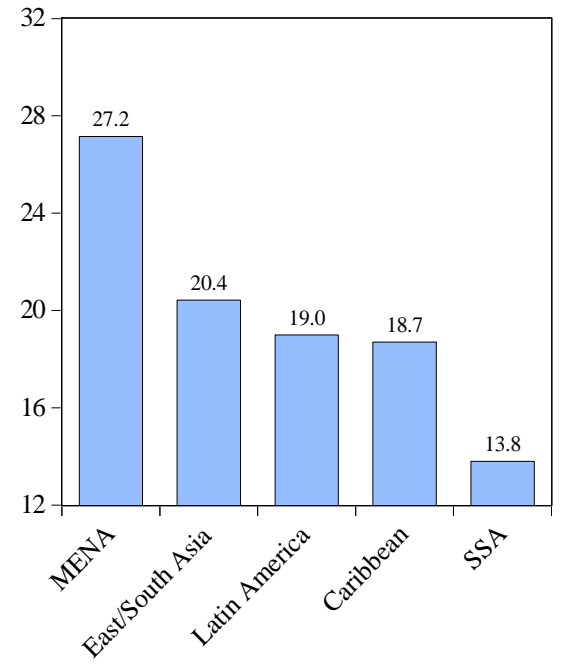

Figure 8: Mean of Index of Polity2 by REGION

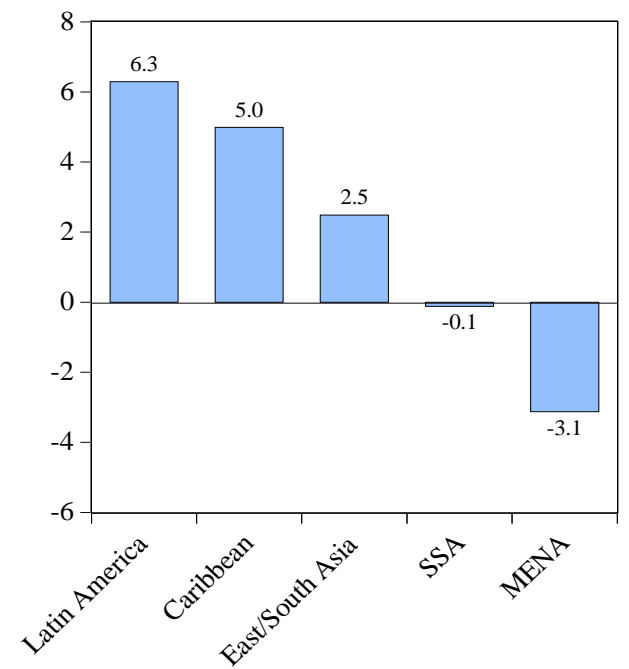

Figure 9: Mean of Inflation, GDP Deflator (Annual \%) by REGION Figure 10: Mean of RGDP Growth Rate (\%) by CORRUPTION PERCEPTION INDEX
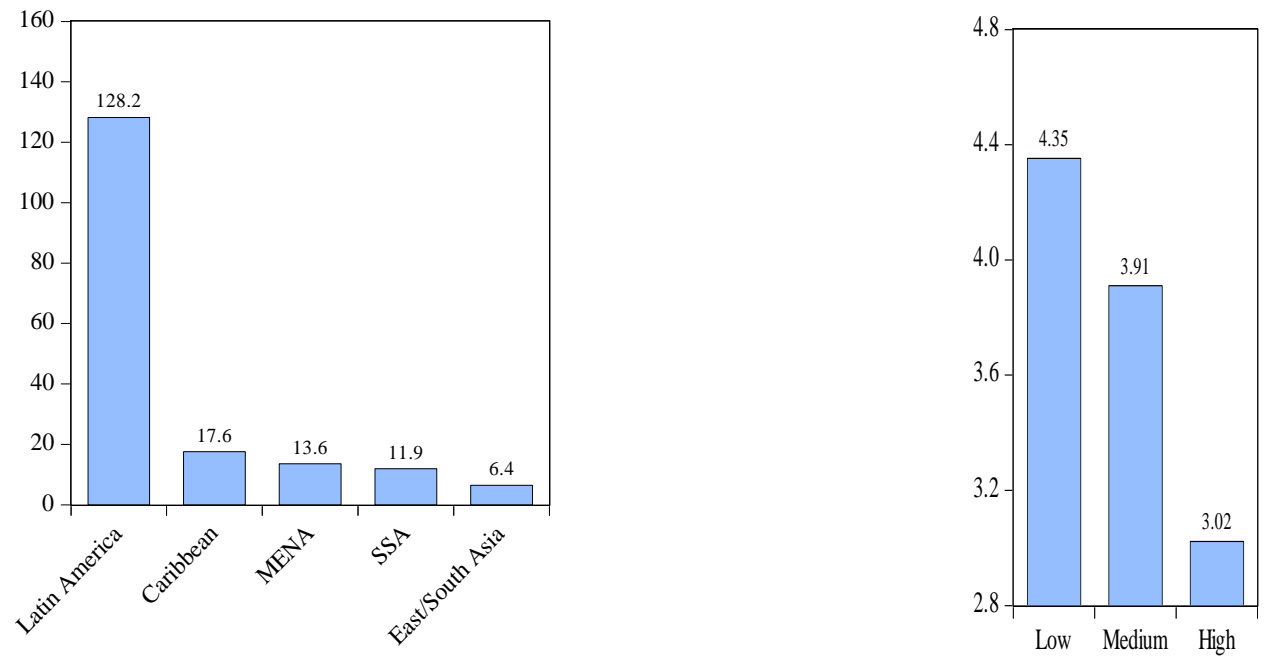


\subsubsection{Stylized Facts}

I construct stylized facts to illustrate the relationship between financial development and its potential determinants, with each dot representing a different country. A regression line is fitted to show the direction of the correlations. Figures 11 through 15 below show the plots of RGDP $\mathrm{t}_{\mathrm{t}-1}$ (log), trade openness, inflation rate, indices of political stability and Polity 2 on the X-axis and the index of financial development on the Y-axis (see Appendix B, Figure 15 for the graph of indices of financial development and Polity2). All the potential determinants are positively correlated with the index of financial development except the inflation rate which exhibits a negative correlation.

Figure 11: Means of Index of Financial Development and RGDP $(\log )$

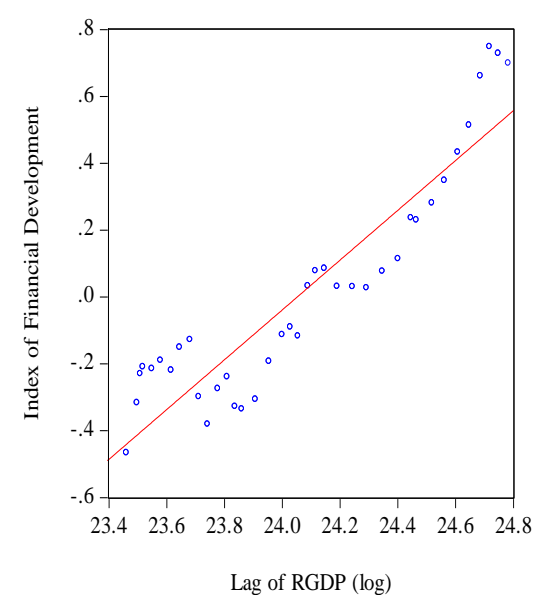

Figure 13: Means of Index of Financial Development and Inflation

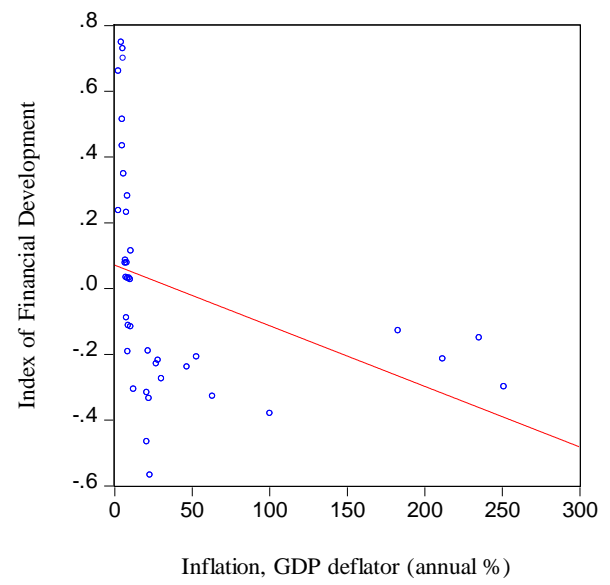

Figure 12: Means of Index of Financial Development and Trade Openness

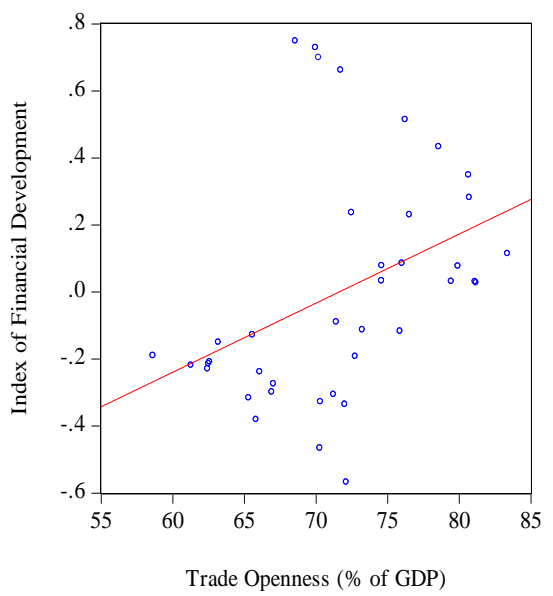

Figure 14: Means of Indices of Financial Developement and Political Stability

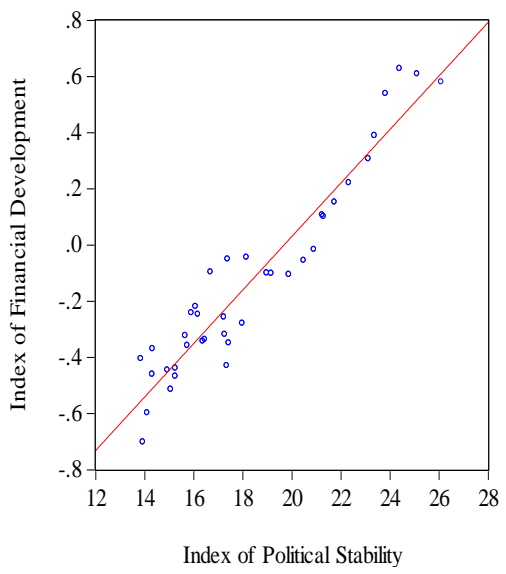




\subsubsection{Unit Root Test}

The study uses the Levin, Lin, and Chu (LLC) unit root test to determine if the variables are stationary or non-stationary (see Levin, Lin, and Chu, 2002). The LLC test has as the null hypothesis that the panels contain a unit root and it assumes that the panels are balanced. The results of the LLC test are presented in Table 9 below. The results show that all the variables are integrated of order zero, $I(0)$; that is, they are stationary at levels.

Table 9: Levin, Lin, and Chu (LLC) Unit Root Test at Levels

\begin{tabular}{|c|c|c|c|}
\hline Variable & None & Individual Effects & $\begin{array}{c}\text { Individual } \\
\text { Effects \& trends }\end{array}$ \\
\hline FINANCE & $-2.88208 * * *$ & 0.99212 & 0.85878 \\
\hline$R G D P_{t-1}(\log )$ & 23.7013 & 4.02338 & $-4.88282 * * *$ \\
\hline$R G D P_{t-1}(\log )(c)$ & 5.96411 & 4.02328 & $-4.88284 * * *$ \\
\hline Trade Openness & $-1.53598^{*}$ & $-2.28728 * *$ & -0.41668 \\
\hline Trade Openness (c) & $-6.14888 * * *$ & $-2.28728 * *$ & -0.41668 \\
\hline FDI, Net inflow & $-7.69436 * * *$ & $-5.43892 * * *$ & $-4.89136 * * *$ \\
\hline FDI, Net inflow (c) & $-10.9813 * * *$ & $-5.43892 * * *$ & $-4.89136 * * *$ \\
\hline Inflation & $-15.1695 * * *$ & $-11.9788 * * *$ & $-12.7190 * * *$ \\
\hline Inflation $(c)$ & -1.03466 & $-11.9788 * * *$ & $-12.7190 * * *$ \\
\hline Index of Polity2 & $-1.66802 * *$ & $-6.73395 * * *$ & $-13.6259 * * *$ \\
\hline Index of Political Stability & 75.0056 & 6.19904 & $-10.3870 * * *$ \\
\hline
\end{tabular}

Source: Author's computation (2020)

Note: $* * *, * *$, and $*$ denote stationary at $1 \%, 5 \%$, and $10 \%$ levels of significance respectively.

(c) defines mean-centered variable 


\subsection{Discussion of Empirical Findings}

I employed the robust Sargan-Hansen test to determine the appropriate estimator to use. The test suggested that the fixed effect estimator is appropriate. Consequently, I respecify equation (1) to have an entity and time fixed effects as:

$$
\boldsymbol{F I N A N C E}_{i t}=\boldsymbol{X}_{i t \boldsymbol{\beta}} \boldsymbol{\beta} \boldsymbol{C}_{\boldsymbol{i}} \boldsymbol{\delta}+\boldsymbol{T}_{\boldsymbol{t}} \boldsymbol{\theta}+\varepsilon_{i t}, \quad i=1,2, \ldots, 69 ; t=1,2, \ldots, 39
$$

Where $\boldsymbol{C}_{\boldsymbol{i}}$ is a vector containing the entity (country) fixed effects and $\boldsymbol{\delta}$ is a vector containing the coefficients of the binary entity regressors. Since $\boldsymbol{C}$ contains binary variables, there are $i-1$ entities in the model. $\boldsymbol{T}_{t}$ and $\boldsymbol{\theta}$ are vectors containing the binary time fixed effects and their coefficients respectively. Since $\boldsymbol{T}$ contains binary variables, there are $t-1$ time periods in the model. Time fixed effect controls for aggregate time trends that may influence FINANCE.

I estimate equation (2) with the mean-centered $\operatorname{RGDP}_{t-1}(\log )$, trade openness and its squared term, and inflation. This is important because of the issue of multicollinearity that arises when using quadratics and interactions. Table 10 in Appendix A show the correlation matrix of trade openness. For instance, trade openness and its squared form have a correlation of $92 \%$; however, the correlation between the centered trade openness and its squared term (centered) used in the regressions is $77 \%$. Additionally, trade openness and its centered form have a correlation of $100 \%$ and trade openness (squared) and the centered trade openness (squared) have a correlation of $96 \%$. This shows that the mean-centered trade openness and its squared term are measuring the same effect as trade openness and its squared term but do not cause the problem of multicollinearity that the uncentered versions cause. (D) denote that the variable is categorical using binary coding. 
Table 11: Two-Way Fixed Effects Results (1980-2018) for 69 Countries

\begin{tabular}{|c|c|c|c|c|}
\hline VARIABLES & $\begin{array}{c}(1) \\
\text { FINANCE }\end{array}$ & $\begin{array}{c}(2) \\
\text { FINANCE } \\
\end{array}$ & $\begin{array}{c}(3) \\
\text { FINANCE }\end{array}$ & $\begin{array}{c}(4) \\
\text { FINANCE } \\
\end{array}$ \\
\hline $\operatorname{RGDP}_{\mathrm{t}-1}(\log )$ & $\begin{array}{c}1.398 * * * \\
(0.339)\end{array}$ & $\begin{array}{c}1.398 * * * \\
(0.339)\end{array}$ & $\begin{array}{c}1.398 * * * \\
(0.339)\end{array}$ & $\begin{array}{c}1.621 * * * \\
(0.371)\end{array}$ \\
\hline Trade Openness & $\begin{array}{c}0.00947 * * * \\
(0.00239)\end{array}$ & $\begin{array}{c}0.00947 * * * \\
(0.00239)\end{array}$ & $\begin{array}{c}0.00947 * * * \\
(0.00239)\end{array}$ & $\begin{array}{c}0.00866^{* * * *} \\
(0.00253)\end{array}$ \\
\hline Trade Openness ${ }^{2}$ & $\begin{array}{c}-0.0000161 * * \\
(0.00000737)\end{array}$ & $\begin{array}{c}-0.0000161 * * \\
(0.00000737)\end{array}$ & $\begin{array}{r}-0.0000161 * * \\
(0.00000737)\end{array}$ & $\begin{array}{l}-0.0000137 * \\
(0.00000804)\end{array}$ \\
\hline Inflation & $\begin{array}{c}0.00000992 \\
(0.0000606)\end{array}$ & $\begin{array}{l}0.00000992 \\
(0.0000606)\end{array}$ & $\begin{array}{l}0.00000992 \\
(0.0000606)\end{array}$ & $\begin{array}{c}-0.00000406 \\
(0.000058)\end{array}$ \\
\hline Fuel-exporting Countries (D) & $\begin{array}{c}-6.388 * * * \\
(1.655)\end{array}$ & $\begin{array}{c}-4.272 * * * \\
(1.388)\end{array}$ & $\begin{array}{c}-4.272 * * * \\
(1.388)\end{array}$ & $\begin{array}{c}-5.139 * * * \\
(1.523)\end{array}$ \\
\hline Index of Polity 2 & $\begin{array}{c}-0.0324 * * \\
(0.0130)\end{array}$ & $\begin{array}{c}-0.0324 * * \\
(0.0130)\end{array}$ & $\begin{array}{c}-0.0324 * * \\
(0.0130)\end{array}$ & \\
\hline Index of Polity $2^{2}$ & $\begin{array}{c}0.00551^{* *} \\
(0.00247)\end{array}$ & $\begin{array}{c}0.00551 * * \\
(0.00247)\end{array}$ & $\begin{array}{c}0.00551 * * \\
(0.00247)\end{array}$ & \\
\hline Index of Political Stability & $\begin{array}{l}-0.0144^{*} \\
(0.00854)\end{array}$ & $\begin{array}{l}-0.0144 * \\
(0.00854)\end{array}$ & $\begin{array}{l}-0.0144 * \\
(0.00854)\end{array}$ & \\
\hline Index of Political Stability ${ }^{2}$ & $\begin{array}{c}0.000296 * * \\
(0.000140)\end{array}$ & $\begin{array}{c}0.000296 * * \\
(0.000140)\end{array}$ & $\begin{array}{c}0.000296 * * \\
(0.000140)\end{array}$ & \\
\hline Landlocked countries (D) & $\begin{array}{c}-1.192 * * * \\
(0.231)\end{array}$ & $\begin{array}{c}-1.192 * * * \\
(0.231)\end{array}$ & & $\begin{array}{c}-1.366 * * * \\
(0.243)\end{array}$ \\
\hline Least Developed countries (D) & $\begin{array}{c}-2.116 * * * \\
(0.297)\end{array}$ & & & \\
\hline Christian countries (D) & $\begin{array}{c}5.216^{* * * *} \\
(1.247)\end{array}$ & $\begin{array}{c}3.100 * * * \\
(0.981)\end{array}$ & & $\begin{array}{c}3.764 * * * \\
(1.073)\end{array}$ \\
\hline Other religions (D) & $\begin{array}{c}-5.016 * * * \\
(1.256)\end{array}$ & $\begin{array}{c}-2.900 * * * \\
(1.001)\end{array}$ & & \\
\hline Constant & $\begin{array}{c}4.322 * * * \\
(1.238)\end{array}$ & $\begin{array}{c}2.206 * * \\
(0.979)\end{array}$ & $\begin{array}{c}2.206 * * \\
(0.979)\end{array}$ & $\begin{array}{c}3.080 * * * \\
(1.072)\end{array}$ \\
\hline $\begin{array}{l}\text { Observations } \\
\text { R-squared }\end{array}$ & $\begin{array}{l}2,614 \\
0.850\end{array}$ & $\begin{array}{l}2,614 \\
0.850\end{array}$ & $\begin{array}{l}2,614 \\
0.850\end{array}$ & $\begin{array}{l}2,614 \\
0.842\end{array}$ \\
\hline Sargan-Hansen Test & $p=0.0000$ & - & - & - \\
\hline Wald Test (Covariates) & $p=0.0000$ & - & - & - \\
\hline Wald Test (Entity Effects) & $p=0.0000$ & - & - & - \\
\hline Wald Test (Time Effects) & $p=0.0000$ & - & - & - \\
\hline
\end{tabular}

Robust standard errors in parentheses $* * * \mathrm{p}<0.01, * * \mathrm{p}<0.05, * \mathrm{p}<0.1$ 
Equations (2), (3), and (4) are parsimonious models while equation (1), the most preferred model, is the general model considering only the variables in Table 11. The signs, magnitudes, and significance of the variables are stable with the R-squared being about $85 \%$ in all equations. The Sargan-Hansen and the Wald tests are significant in all equations. The Wald test suggests that the covariates, time, and entity fixed effects are jointly and statistically different from zero, respectively.

The empirical result confirms that the real gross domestic product (a proxy for national income) is positively associated with financial development. Also, the size of the effect is both statistically and economically relevant. This result confirms the first correlation plot (Figure 10). This effect can be explained by the fact that industrialization and sustained economic growth enhances the supply of and demand for financial services and credit. The higher the national income, the higher the chances that the people can acquire education and financial literacy which enables them to demand financial services. Also, savings tend to increase as income increases. As a result, savers can buy financial securities and/or make deposits in banks. Increased savings lubricates the intermediation process and in turn, encourages financial development.

Similarly, trade openness has a positive and robust impact on financial development; however, the squared term suggests that trade openness has a declining marginal effect on financial development when trade exceeds 354.85 percent of GDP (see Appendix B, Figure 16 for graph and Appendix A, Table 12 for turning point). This effect should be interpreted with caution. A survey of the dataset shows that only Singapore has reached this turning point, recording a value of 437.33 percent in 2008. However, trade openness in Singapore from 2015 to 2018 has been below the threshold. Besides, most developing countries are well below the turning point, most have not attained up to 110 percent. A good way to explain this effect is that trade openness 
engenders competition and a robust institutional framework. The conclusion is that developing countries should work to open their economies to international trade since it can boost financial development; however, the degree of openness should be contingent on the country's pre-existing macroeconomic conditions by making sure that openness will not jeopardize the growth of the country's manufacturing sector. The Inflation rate is not important for explaining differences in the level of financial development across developing countries. This result agrees with the findings of Outreville (1999).

The indices of Polity 2 and political stability have a quadratic impact on financial development. Polity 2 and political stability begin to contribute positively to financial development after a certain threshold (see Appendix B, Figures 18 and 17 for graphs and Appendix A, Table 12 for turning point). The curve of Polity 2 slopes upward after a score of 3 while that of the index of political stability starts at a score of 24. Figures 15 and 18 (both in Appendix B) makes the explanation of Polity2 a bit ambiguous. However, I argue that democracy and autocracy, in their own rights, might not matter for financial and economic development. What matters is the establishment of inclusive political and economic institutions that provide to a vast majority of the people the incentives to innovate and work, a disinterested legal system, public services, secure property rights, and the right to choose. ${ }^{8}$ It is worthy to note that more democratization tends to encourage inclusiveness. Additionally, politically stable countries have higher levels of financial development. Political instability leads to insecure property rights and can have a negative impact on the confidence of economic agents which can adversely affect their supply of savings in the

\footnotetext{
${ }^{8}$ See Acemoglu and Robinson (2012) for more discussion on institutions and prosperity
} 
forms of bank deposits and the purchase of financial securities. It is important to note that all the turning points fall within the range of the data.

Fuel-exporting countries, landlocked countries, and least developed countries tend to have lower levels of financial development. One way to explain the lower level of financial development of fuel-exporting countries is the lack of inclusive institutions in these countries which leads to rent-seeking (corruption) and socio-economic inequalities caused by uneven income distribution and the monocultural economies of these countries. This effect can inversely affect the demand and supply of financial services. The effect of geography, lack of territorial access to the sea, on financial development is indirect. This is true because landlocked countries tend to have a lower level of economic growth because they face higher trade transaction costs and lower volume of trade (Arvis et al., 2011). Landlocked countries must make efforts to make air transport and telecommunication services less restrictive to connect the countries with the rest of the world (Borchert et al., 2012).

The low level of national income, the presence of extractive (weak) institutions, and political instability are some of the reasons why the least developed countries have a lower level of financial development. Countries with a predominantly Christian population have a higher level of financial development than predominantly Muslim countries and other non-Christian majority countries. A possible explanation is that countries with the largest Christian populations tend to have more inclusive institutions that stimulate competition, robust institutional quality, and the spirit of enterprise. It is worthy to note that one determinant alone cannot achieve financial and economic development which is a multidimensional and dynamic process. What is required is a comprehensive and, if possible, simultaneous improvement in the economic, political, institutional, geographical, and socio-cultural factors identified in this study. 
Table 13: Two-Way Fixed Effects Results (1980-2018) for 69 Countries with Regions

\begin{tabular}{|c|c|c|c|c|}
\hline VARIABLES & $\begin{array}{c}(1) \\
\text { FINANCE }\end{array}$ & $\begin{array}{c}(2) \\
\text { FINANCE }\end{array}$ & $\begin{array}{c}(3) \\
\text { FINANCE }\end{array}$ & $\begin{array}{c}(4) \\
\text { FINANCE }\end{array}$ \\
\hline $\operatorname{RGDP}_{\mathrm{t}-1}(\log )$ & $\begin{array}{c}1.194 * * * \\
(0.235)\end{array}$ & $\begin{array}{c}1.808 * * * \\
(0.319)\end{array}$ & $\begin{array}{c}0.942 * * * \\
(0.286)\end{array}$ & $\begin{array}{c}1.661 * * * \\
(0.358)\end{array}$ \\
\hline Trade Openness & $\begin{array}{c}0.00879 * * * \\
(0.00236)\end{array}$ & $\begin{array}{c}0.00761 * * * \\
(0.00245)\end{array}$ & $\begin{array}{c}0.00785^{* * *} \\
(0.00236)\end{array}$ & $\begin{array}{c}0.00838^{* * * *} \\
(0.00254)\end{array}$ \\
\hline Trade Openness ${ }^{2}$ & $\begin{array}{c}-0.0000169 * * \\
(0.00000728)\end{array}$ & $\begin{array}{l}-0.0000138^{*} \\
(0.00000758)\end{array}$ & $\begin{array}{c}-0.0000168 * * \\
(0.00000766)\end{array}$ & $\begin{array}{l}-0.0000141^{*} \\
(0.00000799)\end{array}$ \\
\hline Inflation & $\begin{array}{c}0.0000106 \\
(0.0000663)\end{array}$ & $\begin{array}{c}0.0000109 \\
(0.0000597)\end{array}$ & $\begin{array}{c}-0.000011 \\
(0.0000588)\end{array}$ & $\begin{array}{r}0.00000372 \\
(0.0000571)\end{array}$ \\
\hline Sub-Saharan Africa (D) & $\begin{array}{c}-1.087 * * * \\
(0.168)\end{array}$ & $\begin{array}{c}-1.801 * * * \\
(0.260)\end{array}$ & $\begin{array}{c}-0.957 * * * \\
(0.182)\end{array}$ & $\begin{array}{c}-1.269 * * * \\
(0.214)\end{array}$ \\
\hline MENA (D) & $\begin{array}{c}1.360 * * * \\
(0.476)\end{array}$ & $\begin{array}{l}1.303 * \\
(0.727)\end{array}$ & $\begin{array}{c}5.801 * * * \\
(1.371)\end{array}$ & $\begin{array}{c}0.757 \\
(0.770)\end{array}$ \\
\hline East and South Asia (D) & $\begin{array}{c}1.408 * * * \\
(0.401)\end{array}$ & $\begin{array}{c}1.674 * * * \\
(0.516)\end{array}$ & $\begin{array}{c}3.491 * * * \\
(0.537)\end{array}$ & $\begin{array}{l}1.109 * * \\
(0.553)\end{array}$ \\
\hline Latin America (D) & $\begin{array}{c}0.249 \\
(0.310)\end{array}$ & $\begin{array}{l}-0.125 \\
(0.342)\end{array}$ & $\begin{array}{c}0.701 * * * \\
(0.0690)\end{array}$ & $\begin{array}{l}-0.568 \\
(0.393)\end{array}$ \\
\hline Least Developed countries (D) & $\begin{array}{c}-0.599 * * \\
(0.263)\end{array}$ & $\begin{array}{c}-0.792 * * \\
(0.361)\end{array}$ & & $\begin{array}{c}-1.144 * * * \\
(0.398)\end{array}$ \\
\hline High Corruption (D) & $\begin{array}{c}-1.450 * * * \\
(0.370)\end{array}$ & $\begin{array}{c}-1.377 * * * \\
(0.485)\end{array}$ & $\begin{array}{c}-2.443 * * * \\
(0.582)\end{array}$ & $\begin{array}{c}-1.934 * * * \\
(0.518)\end{array}$ \\
\hline Medium Corruption (D) & $\begin{array}{r}-0.0615 \\
(0.318)\end{array}$ & & & $\begin{array}{c}-1.145^{* * * *} \\
(0.413)\end{array}$ \\
\hline Christian countries (D) & $\begin{array}{c}4.641 * * * \\
(0.866)\end{array}$ & $\begin{array}{c}6.387 * * * \\
(1.195)\end{array}$ & $\begin{array}{c}7.617 * * * \\
(1.279)\end{array}$ & $\begin{array}{c}5.856 * * * \\
(1.330)\end{array}$ \\
\hline Index of Political Stability & $\begin{array}{l}-0.00810 \\
(0.00611)\end{array}$ & & & $\begin{array}{l}0.0150 * * \\
(0.00626)\end{array}$ \\
\hline $\mathrm{RGDP}_{\mathrm{t}-1} *$ Political Stability & $\begin{array}{c}0.00846 * * * \\
(0.00241)\end{array}$ & & & \\
\hline Index of Polity 2 & $\begin{array}{c}-0.0341 * * \\
(0.0132)\end{array}$ & & & \\
\hline Index of Polity $2^{2}$ & $\begin{array}{c}0.00577 * * \\
(0.00270)\end{array}$ & & & \\
\hline $\mathrm{RGDP}_{\mathrm{t}-1} * \mathrm{SSA}$ & & $\begin{array}{l}-0.755^{* * * *} \\
(0.242)\end{array}$ & & \\
\hline $\mathrm{RGDP}_{\mathrm{t}-1} * \mathrm{ES}$ Asia & & & $\begin{array}{l}0.927 * * * \\
(0.310)\end{array}$ & \\
\hline Political Stability * SSA & & & & $\begin{array}{c}-0.0226 * * \\
(0.0104)\end{array}$ \\
\hline Constant & $\begin{array}{c}-1.814 * * * \\
(0.557)\end{array}$ & $\begin{array}{c}-2.389 * * * \\
(0.510)\end{array}$ & $\begin{array}{c}-4.445 * * * \\
(0.659)\end{array}$ & $\begin{array}{l}-0.990 \\
(0.730)\end{array}$ \\
\hline Observations & 2,614 & 2,614 & 2,614 & 2,614 \\
\hline R-squared & 0.858 & 0.851 & 0.854 & 0.847 \\
\hline Sargan-Hansen Test & $p=0.000$ & - & - & - \\
\hline
\end{tabular}


Table 13 presents the regression results after controlling for regions. Equation (1) is the general equation and the most preferred. Other equations are parsimonious. The Sargan-Hansen and the Wald tests are all significant though I have reported only the former. The covariates explain about 85 percent of the variations in FINANCE in all equations. Out of the five regions, East and South Asia has the highest level of financial development while sub-Saharan Africa has the lowest level of financial development. The Middle East and North Africa (MENA) region has a higher level of financial development than Latin America and the Caribbean that have comparable levels of financial development.

One way to explain this difference in the level of financial development across the regions is the difference in the level of economic development, including differences in the levels of human development indicators. Also, political, institutional, and geography factors play important roles because most sub-Saharan African countries, apart from being landlocked, tend to have higher political instability (see Figure 7 above), higher corruption levels, and weaker institutions. Furthermore, institutional quality plays a crucial role in explaining cross-country financial development differential. Countries with high perceived levels of corruption (ranging from 101 to 180) and countries with medium perceived levels of corruption (ranging from 61 to 100) have lower levels of financial development than countries with low perceived levels of corruption (ranging from 1 to 60 ). A higher level of corruption is detrimental to robust institutional quality, industrialization, rule of law, infrastructural development, security, political stability, competition, social trust, and meritocracy and affects the demand and supply of financial services.

The interaction term between national income and political stability suggests that the impact of national income on financial development depends on the level of political stability. This means that national income has a larger effect on financial development as the political climate 
becomes more stable. Also, the interaction term between national income and the binary variable for sub-Saharan Africa suggests that sub-Saharan Africa has a lower level of financial development than the Caribbean as national income increases across the two regions. Similarly, the interaction term between political stability and the binary variable for sub-Saharan Africa suggests that subSaharan Africa has a lower level of financial development than the Caribbean even when both regions have a more stable political environment. On the other hand, the interaction term between national income and the binary variable for East and South Asia shows that East and South Asia has a higher level of financial development than the Caribbean as national income increases across the two regions.

I estimate a growth model, using two-way fixed effects and clustered standard errors, to re-examine the impact of financial development on the economic growth of the developing countries studied. The index of financial development is in lag to account for simultaneity bias while national income is not in lag form. New variables, such as the net inflow of foreign direct investment, small developing Islands (a binary variable), and BRICS, a binary variable for the emerging economies of Brazil, Russia (not included in the sample due to data inadequacy), India, China, and South Africa, are introduced.

Table 14 below gives the results of the growth regressions. Equations (2), (3), and (4) are parsimonious models while equation (1), the most preferred model, is the general model. The signs, magnitudes, and significance of the variables are generally stable with the R-squared being about 99\% in all equations. The Sargan-Hansen and Wald tests are significant in all equations. 
Table 14: Growth Regressions for 69 Countries from 1980 to 2018

\begin{tabular}{|c|c|c|c|c|}
\hline VARIABLES & $\begin{array}{c}\text { (1) } \\
\text { RGDP }(\log )\end{array}$ & $\begin{array}{c}\text { (2) } \\
\text { RGDP }(\log )\end{array}$ & $\begin{array}{c}\text { (3) } \\
\text { RGDP }(\log ) \\
\end{array}$ & $\begin{array}{c}(4) \\
\text { RGDP }(\log ) \\
\end{array}$ \\
\hline FINANCE $_{t-1}$ & $\begin{array}{c}0.0374 * * \\
(0.0176)\end{array}$ & $\begin{array}{c}0.0374 * * \\
(0.0176)\end{array}$ & $\begin{array}{c}0.0472 * * \\
(0.0178)\end{array}$ & $\begin{array}{c}0.0472 * * \\
(0.0178)\end{array}$ \\
\hline FINANCE $_{t-1}{ }^{2}$ & $\begin{array}{c}0.0110^{*} \\
(0.00555)\end{array}$ & $\begin{array}{c}0.0110^{*} \\
(0.00555)\end{array}$ & $\begin{array}{c}0.0105^{*} \\
(0.00579)\end{array}$ & $\begin{array}{c}0.0105^{*} \\
(0.00579)\end{array}$ \\
\hline Trade Openness & $\begin{array}{c}0.000120 \\
(0.000576)\end{array}$ & $\begin{array}{c}0.000120 \\
(0.000576)\end{array}$ & $\begin{array}{c}0.000155 \\
(0.000600)\end{array}$ & $\begin{array}{c}0.000155 \\
(0.000600)\end{array}$ \\
\hline Inflation & $\begin{array}{l}0.000000192 \\
(0.00000601)\end{array}$ & $\begin{array}{l}0.000000192 \\
(0.00000601)\end{array}$ & $\begin{array}{c}-0.00000372 \\
(0.00000661)\end{array}$ & $\begin{array}{c}-0.00000372 \\
(0.00000661)\end{array}$ \\
\hline FDI, Net Inflow & $\begin{array}{l}-0.00144 \\
(0.00184)\end{array}$ & $\begin{array}{l}-0.00144 \\
(0.00184)\end{array}$ & $\begin{array}{l}-0.00117 \\
(0.00201)\end{array}$ & $\begin{array}{l}-0.00117 \\
(0.00201)\end{array}$ \\
\hline Fuel-exporting Countries (D) & $\begin{array}{c}4.038^{* * * *} \\
(0.0295)\end{array}$ & $\begin{array}{c}4.038^{* * * *} \\
(0.0295)\end{array}$ & $\begin{array}{c}4.019^{* * * *} \\
(0.0277)\end{array}$ & $\begin{array}{c}4.019 * * * \\
(0.0277)\end{array}$ \\
\hline Small Developing Islands (D) & $\begin{array}{c}-4.031 * * * \\
(0.0447)\end{array}$ & $\begin{array}{c}-4.031 * * * \\
(0.0447)\end{array}$ & $\begin{array}{c}-4.022 * * * \\
(0.0445)\end{array}$ & $\begin{array}{c}-2.835^{* * * *} \\
(0.0153)\end{array}$ \\
\hline High Corruption (D) & $\begin{array}{c}-2.766 * * * * \\
(0.0320)\end{array}$ & $\begin{array}{c}-2.766 * * * \\
(0.0320)\end{array}$ & $\begin{array}{c}-2.785 * * * \\
(0.0236)\end{array}$ & \\
\hline Medium Corruption (D) & $\begin{array}{c}-1.030^{* * * *} \\
(0.0397)\end{array}$ & $\begin{array}{c}-1.030 * * * \\
(0.0397)\end{array}$ & $\begin{array}{c}-1.053 * * * \\
(0.0254)\end{array}$ & \\
\hline Christian countries (D) & $\begin{array}{l}1.205^{* * * *} \\
(0.0336)\end{array}$ & $\begin{array}{l}1.205^{* * * *} \\
(0.0336)\end{array}$ & $\begin{array}{l}1.187 * * * \\
(0.0305)\end{array}$ & \\
\hline Other religions $(\mathrm{D})$ & $\begin{array}{c}0.987 * * * \\
(0.0386)\end{array}$ & $\begin{array}{c}0.987 * * * \\
(0.0386)\end{array}$ & $\begin{array}{l}1.067 * * * \\
(0.0151)\end{array}$ & \\
\hline Landlocked countries (D) & $\begin{array}{c}-3.428 * * * \\
(0.0496)\end{array}$ & $\begin{array}{c}-3.428 * * * \\
(0.0496)\end{array}$ & $\begin{array}{c}-3.403 * * * \\
(0.0495)\end{array}$ & \\
\hline Index of Polity2 & $\begin{array}{c}-0.000199 \\
(0.00279)\end{array}$ & $\begin{array}{r}-0.000199 \\
(0.00279)\end{array}$ & & \\
\hline Index of Political Stability & $\begin{array}{c}0.00342 * * \\
(0.00144)\end{array}$ & $\begin{array}{c}0.00342 * * \\
(0.00144)\end{array}$ & & \\
\hline BRICS & $\begin{array}{l}1.848^{* * * *} \\
(0.0371)\end{array}$ & & & \\
\hline Constant & $\begin{array}{c}23.62 * * * \\
(0.0605)\end{array}$ & $\begin{array}{c}23.62 * * * \\
(0.0605)\end{array}$ & $\begin{array}{c}23.68 * * * \\
(0.0455)\end{array}$ & $\begin{array}{c}20.90 * * * \\
(0.0442)\end{array}$ \\
\hline Observatio & 2,608 & 2,608 & 2,608 & 2,608 \\
\hline R-squared & 0.993 & 0.993 & 0.993 & 0.993 \\
\hline
\end{tabular}

Robust standard errors in parentheses

$* * * \mathrm{p}<0.01, * * \mathrm{p}<0.05, * \mathrm{p}<0.1$ 
Evidently, financial development is positively and robustly associated with economic growth as measured by real gross domestic product. That is, an improvement in the level of financial development can increase national income. Past results, such as Levine 1991, Calderon and Liu (2003), and others, have found a robust positive correlation between financial development and growth; however, the interesting and innovative finding here is the effect of the quadratic. The finding is that, after accounting for economic, political, institutional, geographical, and sociocultural factors, financial development has an increasing marginal effect on economic growth (see Appendix B, Figure 19 for graph and Appendix A, Table 12 for turning point). This result is intuitive. At higher levels of financial development, the effect of financial development on national income increases.

Furthermore, political stability engenders higher national income. A good way to explain this impact is that political stability increases economic confidence and builds social trust. Also, fuel-exporting countries, BRICS, predominantly Christian countries have a higher level of national income. On the contrary, small island developing states, countries with high and medium perceived levels of corruption, and landlocked countries have lower levels of national income. Trade openness, the net inflow of foreign direct investment, and the inflation rate are not important determinants of cross-country differences in national income. 


\section{CHAPTER FIVE}

\section{Conclusion and Recommendations}

The positive association between financial development and economic growth has encouraged research in the area of the determinants of financial development. The main objective of this paper is to identify the determinants of financial development of 69 developing countries across five regions from 1980 to 2018. This paper explored some popular determinants of financial development in the literature such as national income, trade openness, and inflation, political stability, geographical factors, religious affiliations, and introduced new determinants such as the perception of corruption. Another important contribution of this paper is that it explores the quadratic and interaction effects of these determinants on financial development. I started by testing if the variables are stationary. The results show that the variables are stationary at levels though some of the variables have trends. This study employed the two-way fixed effect, which accounts for both entity and time fixed effects, with clustered standard errors to estimate the equations. In addition, I re-examine the hypothesis that financial development is relevant to the economic growth of developing countries. The results show that the signs, magnitudes, and significance of the variables are stable across specifications.

This study made some interesting, and to the best of my knowledge, innovative findings that make a significant contribution to economics and improve our understanding of the nature of the relationship between financial development and its determinants in developing economies. I find that economic, political, institutional, geographical, and socio-cultural factors account for the differences in the levels of financial development across countries and regions. Specifically, national income, trade openness, indices of Polity2 (democracy score) and political stability, the perceived levels of public sector corruption, territorial disadvantages, and religious composition 
of the country are important determinants of the variations in financial development. The most interesting finding of this paper is in the non-linearities of the determinants. Trade openness has a diminishing marginal effect on financial development only when trade openness reaches 354.85 percent of GDP. Most developing countries are well below this threshold.

Similarly, the indices of political stability and polity 2 show significant non-linearities. The curves of the indices of political stability and democracy are U-shaped, suggesting that political stability and democracy contribute positively to financial development when a score of 24 and 3 are reached respectively. Also, countries with higher levels of corruption have a lower level of financial development. Political and institutional factors have a direct and indirect effect on financial development and can seriously undermine the demand and supply of credit. This underlines the importance of robust institutions if a country wants to achieve a strong financial system. Across the regions, East and South Asia has the highest level of financial development while sub-Saharan Africa has the lowest level of financial development in the world. In addition, fuel-exporting countries, least developed counties, and landlocked countries have relatively lower levels of financial development. Socio-cultural factors also determine a country's level of financial development as predominantly Christian countries experience a higher level of financial development because of superior institutional quality and competitiveness.

There are obvious steps that developing countries can follow to build and sustain a welldeveloped financial sector that can fund a balanced and sustainable economic development. First, critical efforts must be made to grow the economy. As the economy expands, the demand for financial services increases which stimulate financial development. Engaging in international trade also play important roles. Monocultural economies based on crude oil must make efforts to invest crude oil wealth in critical social infrastructure like schools and hospitals and capital goods to build 
a strong manufacturing sector and ensure sustainable development. Landlocked countries should develop their air transport and telecommunication services to ameliorate the effects of their lack of territorial access to the sea. Similarly, efforts must be made to make the country conducive for domestic and foreign investment by building infrastructure, security, and inclusive institutions to increase the production possibilities of the economy. Also, governments in power must endeavor to provide essential services and be accountable to the masses to reduce the likelihood of political instability and conflict. Industrialization does not occur in volatile environments. Financial institutions and markets must be regulated to ensure that they are not incurring excessive risky investments and individual rights must be protected.

Reducing corruption to its barest minimum is crucial if a country wants to achieve sustainable financial and economic development. Fighting corruption is especially important for a country attempting to achieve development because of its ubiquitous effect on the society as a whole and its ability to entrench and sustain extractive institutions that concentrate economic and political powers in the hands of a few elite. An important step towards financial and economic development for developing countries is the transformation of extractive institutions into inclusive ones that extend incentives, freedom, opportunities, and a level playing field to most people. This can be achieved through sustained pressure on the economic and political elite from a broad coalition of diverse interests in the country with support from civil societies and the citizens in the diaspora. Wide-spread corruption causes low domestic and foreign investment due to poor infrastructure and institutions, high socio-economic inequality, brain drain, political instability, a bad reputation for the country, and ultimately low economic growth rates. For future studies, more emphasis should be focused on the factors that encourage governments and policymakers in developing countries to enact policies aimed at achieving a more developed financial sector. 


\section{REFERENCES}

Acemoglu, D. and Robinson, J. (2012). Why Nations Fail: The Origins of Power, Prosperity, and Poverty. New York, NY: Crown.

Ahamed, M. (2016). Does Inclusive Financial Development Matter for Firms' Tax Evasion? Evidence from Developing Countries. Economic Letters, 149: 15-19.

Arvis, J., Carruthers, R., Smith, G., and Willoughby, C. (2011). Connecting Landlocked Developing Countries to Markets: Trade Corridors in the 21st Century. World Bank, Washington D.C. eISBN: 978-0-8213-8417-6

Asghar, N. and Hussain, Z. (2014). Financial Development, Trade Openness and Economic Growth in Developing Countries : Recent Evidence from Panel Data. Pakistan Economic and Social Review, 52(2): 99-126.

Baltalgi, B., Demetriades, P., and Law, S. (2009). Financial Development, Openness, and Institutions: Evidence from Panel Data. Journal of Development Economics, 80: 258-296.

Bangake, C. and Eggoh, J. (2011). Further Evidence on Finance-Growth Causality: A Panel Data Analysis. Economic Systems, 35(2): 176-188.

Beck, T. and Levine, R. (2004). Stock Markets, Banks, and Growth : Panel Evidence. Journal of Banking \& Finance, 28: 423-442.

Beck, T., Demirguc-Kunt, A., and Levine, R. (2003). Law, Endowments, and Finance. Journal of Financial Economics, 70(2): 137-181.

Bhattacharyya, S. and Hodler, R. (2011). Do Natural Resource Revenues Hinder Financial Development? The Role of Political Institutions. Proceedings of the German Development Economics Conference No. 11. Berlin, Germany.

Borchert, I., Gootiiz, B., Grover, A., and Mattoo, A. (2012). Landlocked or Policy Locked? How Services Trade Protection Deepens Economic Isolation. World Bank Policy Research Working Paper No. 5942, Washington D. C. 
Boyd, J. H., Levine, R., and Smith, B. D. (2001). The Impact of Inflation on Financial Sector Performance. Journal of Monetary Economics, 47: 221-248.

Calderón, C. and Liu, L. (2003). The Direction of Causality Between Financial Development and Economic Growth. Journal of Development Economics, 72(1): 321-334.

Cerny, B. and Kaiser, H. (1977). A Study of a Measure of Sampling Adequacy for Factor-Analytic Correlation Matrices. Multivariate Behavioral Research, 12(1): 43-47.

Cherif, M. and Gazdar, K. (2010). Institutional and Macroeconomic Determinants of tock Market Development in MENA Region: New Results from a Panel Data Analysis. International Journal of Banking and Finance, 7(1): 139-159.

Chinn, M. and Ito, H. (2005). What Matters for Financial Development? Capital Controls, Institutions, and Interactions. National Bureau of Economic Research Working Paper Series 11370, Cambridge, MA.

Christopoulos, D. K. and Tsionas, E. G. (2004). Financial Development and Economic Growth : Evidence From Panel Unit Root and Cointegration Tests. Journal of Development Economics. 73: 55-74.

Cull, R. and Effron, L. (2008). World Bank Lending and Financial Sector Development. World Bank Economic Review, 22(2): 315-343.

Datta, S. and Singh, K. (2019). Variation and Determinants of Financial Inclusion and their Association with Human Development: A Cross-Country Analysis. IIMB Management Review, 31: 336-349.

Durusu-Ciftci, D., Ispir, M., and Yetkiner, H. (2017). Financial Development and Economic Growth: Some Theory and More Evidence, Journal of Policy Modeling, 39(2): 290-306.

Enders, C. K. (2010). Applied Missing Data Analysis. New York, NY: The Guilford Press.

Goldsmith, R. (1969). Financial Structure and Development. New Haven, CT: Yale University Press. 
Gupta, S., Pattillo, C., and Wagh, S. (2009). Effects of Remittances on Poverty and Financial Development in sub-Saharan Africa. World Development, 37(1): 104-115.

Hassan, M. K., Sanchez, B., and Yu, J. (2011). Financial Development and Economic Growth : New Evidence from Panel Data. Quarterly Review of Economics and Finance, 51(1): 88104.

Herger, N., Hodler, R., and Lobsiger, M. (2008). What Determines Financial Development? Culture, Institutions or Trade. Review of World Economics, 144(3): 558-587.

Huang, Y. (2005). What Determines Financial Development? Discussion Paper No. 05/580, Department of Economics, University of Bristol.

Huang, Y. (2010). Determinants of Financial Development. Basingstoke, Hampshire: Palgrave Macmillan.

Jeanneney, S. G. and Kpodar, K. (2011). Financial development and Poverty Reduction: Can There be a Benefit without a Cost? Journal of Development Studies, 47(1): 143-163.

Kaiser, H. (1974). An Index of Factorial Simplicity. Psychometrika, 39(1):31-36.

Kappel, V. (2010). The Effects of Financial Development on Income Inequality and Poverty. Economics Working Paper No. 10/127, Center of Economic Research, ETH Zurich.

Karakurum-Ozdemir, K., Kokkizil, M., and Uysal, G. (2019). Financial Literacy in Developing Countries. Social Indicators Research, 143: 325-353.

Karikari, N., Mensah, S., and Harvey, S. (2016). Do Remittances Promote Financial Development in Africa? SpringerPlus, 5: 1-21.

Kim, D. H. and Lin, S. C. (2011). Nonlinearity in the Financial Development-Income Inequality Nexus. Journal of Comparative Economics, 39(3): 310-325.

King, R. and Levine, R. (1993). Finance and Growth: Schumpeter Might be Right. Quarterly Journal of Economics, 108(3): 717-738. 
Law, S. H., Tan, H. B., and Azman-Saini, W. N. W. (2014). Financial Development and Income Inequality at Different Levels of Institutional Quality. Emerging Markets Finance and Trade, 50(Supplement 1): 21-33.

Leon, F. and Zins, A. (2020). Regional Foreign Banks and Financial Inclusion: Evidence from Africa. Economic Modelling, 84(C): 102-116.

Levin, A., Lin, C., and Chu, C. (2002). Unit Root Tests in Panel Data: Asymptotic and FiniteSample Properties. Journal of Econometrics, 108(1): 1-24.

Levine, R. (1991). Stock Markets, Growth, and Tax Policy. Journal of Finance, 46(4): 1445-1465.

Levine, R. (1997). Financial Development and Economic Growth: Views and Agenda. Journal of Economic Literature, 35(2): 688-726.

McKinnon, R. (1973). Money and Capital in Economic Development. Washington DC: Brookings Institution.

Munemo, J. (2017). Foreign Direct Investment and Business Start-up in Developing Countries: The Role of Financial Market Development. Quarterly Review of Economics and Finance, 65(C): 97-106.

Park, D. and Shin, K. (2017). Economic Growth, Financial Development, and Income Inequality. Emerging Markets Finance and Trade, 53(12): 2794-2825.

Patrick, H. (1966). Financial Development and Economic Growth in Underdeveloped Countries. Economic Development and Cultural Change, 14(2): 174-189.

Organization for Economic Co-operation and Development (2008). Handbook on Constructing Composite Indicators: Methodology and User Guide. ISBN 978-92-64-04345-9.

Outreville, J. F. (1999). Financial Development, Human Capital and Political Stability. United Nations Conference on Trade and Development Discussion Papers No. 142, Geneva, Switzerland. 
Raza, S., Shahzadi, H., and Akram, M. (2014). Exploring the Determinants of Financial Development (Using Panel Data on Developed and Developing Countries). Journal of Finance and Economics, 2(5): 166-172.

Roe, M. J. and Siegel, J. I. (2011). Political instability: Effects on Financial Development, Roots in the Severity of Economic Inequality. Journal of Comparative Economics, 39(3): 279309.

Saidi, K. and Mbarek, M. (2017). The Impact of Income, Trade, Urbanization, and Financial Development on $\mathrm{CO}_{2}$ Emissions in 19 Emerging Economies. Environmental Science and Pollution Research, 24: 12748-12757.

Shaw, E. (1973). Financial Deepening in Economic Development. New York: Oxford University Press.

Stulz, R. and Williamson, R. (2003). Culture, Openness, and Finance. Journal of Financial Economics, 70(2): 313-349.

Temin, P. (2010). The Great Recession \& the Great Depression. Daedalus 139.4: 115-124.

United Nations (2018). World Economic Situation and Prospects. eISBN: 978-92-1-362882-9.

Voghouei, H., Azali, M., and Jamali, M. (2011). A Survey of the Determinants of Financial Development. Asian-Pacific Economic Literature, 25(2): 1-20.

Xu, X. (2019). Trust and Financial Inclusion: A Cross-Country Study. Finance Research Letters. ISSN: 15446123. 


\section{APPENDIX A (TABLES)}

Table 1: List of the 69 Countries by Regions

\begin{tabular}{|c|c|c|c|c|}
\hline Sub-Saharan Africa & $\begin{array}{l}\text { East and South } \\
\text { Asia }\end{array}$ & Latin America & Caribbean & MENA \\
\hline $\begin{array}{l}\text { Benin } \\
\text { Botswana } \\
\text { Burkina Faso } \\
\text { Cameroon } \\
\text { Central African Rep. } \\
\text { Chad } \\
\text { Congo, Republic } \\
\text { Cote d'Ivoire } \\
\text { Eswatini } \\
\text { Gabon } \\
\text { Gambia, The } \\
\text { Ghana } \\
\text { Kenya } \\
\text { Madagascar } \\
\text { Malawi } \\
\text { Mali } \\
\text { Mauritius } \\
\text { Niger } \\
\text { Nigeria } \\
\text { Rwanda } \\
\text { Senegal } \\
\text { Sierra Leone } \\
\text { South Africa } \\
\text { Sudan } \\
\text { Togo } \\
\text { Zambia }\end{array}$ & $\begin{array}{l}\text { Bangladesh } \\
\text { China } \\
\text { Fiji } \\
\text { India } \\
\text { Indonesia } \\
\text { Malaysia } \\
\text { Pakistan } \\
\text { Philippines } \\
\text { Singapore } \\
\text { South Korea } \\
\text { Sri Lanka } \\
\text { Thailand }\end{array}$ & $\begin{array}{l}\text { Argentina } \\
\text { Bolivia } \\
\text { Brazil } \\
\text { Chile } \\
\text { Colombia } \\
\text { Costa Rica } \\
\text { Ecuador } \\
\text { El Salvador } \\
\text { Guatemala } \\
\text { Honduras } \\
\text { Mexico } \\
\text { Nicaragua } \\
\text { Panama } \\
\text { Paraguay } \\
\text { Peru } \\
\text { Uruguay }\end{array}$ & $\begin{array}{l}\text { Dominica Rep. } \\
\text { Guyana } \\
\text { Haiti } \\
\text { Jamaica } \\
\text { Suriname } \\
\text { Trinidad and Tobago }\end{array}$ & $\begin{array}{l}\text { Algeria } \\
\text { Egypt } \\
\text { Israel } \\
\text { Jordan } \\
\text { Morocco } \\
\text { Oman } \\
\text { Saudi Arabia } \\
\text { Tunisia } \\
\text { Turkey }\end{array}$ \\
\hline
\end{tabular}


Table 4: Countries by other Classifications (United Nations, 2019)

\begin{tabular}{lllll}
\hline \hline $\begin{array}{l}\text { Least Developed } \\
\text { Countries (as of } \\
\text { March 2018) }\end{array}$ & $\begin{array}{l}\text { Fuel-Exporting } \\
\text { Countries }\end{array}$ & $\begin{array}{l}\text { Landlocked } \\
\text { Developing } \\
\text { Countries }\end{array}$ & $\begin{array}{l}\text { Small Island Developing } \\
\text { States (SDIS) }\end{array}$ & BRICS \\
\hline \hline Bangladesh & Algeria & Bolivia & Dominica Rep. & Brazil \\
Benin & Bolivia & Botswana & Fiji & China \\
Burkina Faso & Cameroon & Burkina Faso & Guyana & India \\
Central African Rep. & Chad & Central African Rep. Haiti & South Africa \\
Chad & Colombia & Chad & Jamaica & Mauritius \\
Haiti & Congo Rep & Eswatini & Singapore & \\
Gambia, The & Gabon & Malawi & Suriname & \\
Madagascar & Ecuador & Mali & Trinidad and Tobago & \\
Malawi & Indonesia & Niger & & \\
Mali & Nigeria & Paraguay & & \\
Niger & Oman & Rwanda & & \\
Rwanda & Saudi Arabia & Zambia & & \\
Senegal & Sudan & & & \\
Sierra Leone & Trinidad and Tobago & & \\
Sudan & & & & \\
Togo & & & & \\
Zambia & & & &
\end{tabular}


Table 5: Countries by Perception of Corruption, Transparency International (2018, A-Z)

\begin{tabular}{|c|c|c|}
\hline Low $(1-60)$ & Medium (61-100) & High (101-180) \\
\hline $\begin{array}{l}\text { Botswana } \\
\text { Chile } \\
\text { Costa Rica } \\
\text { Israel } \\
\text { Jordan } \\
\text { Mauritius } \\
\text { Oman } \\
\text { Rwanda } \\
\text { Saudi Arabia } \\
\text { Singapore } \\
\text { South Korea } \\
\text { Thailand } \\
\text { Uruguay }\end{array}$ & $\begin{array}{l}\text { Argentina } \\
\text { Benin } \\
\text { Burkina Faso } \\
\text { China } \\
\text { Colombia } \\
\text { Eswatini } \\
\text { Gambia, The } \\
\text { Ghana } \\
\text { Guyana } \\
\text { India } \\
\text { Indonesia } \\
\text { Jamaica } \\
\text { Malaysia } \\
\text { Mali } \\
\text { Morocco } \\
\text { Panama } \\
\text { Philippines } \\
\text { Senegal } \\
\text { South Africa } \\
\text { Sri Lanka } \\
\text { Suriname } \\
\text { Trinidad \& Tobago } \\
\text { Tunisia } \\
\text { Turkey }\end{array}$ & $\begin{array}{l}\text { Algeria } \\
\text { Bangladesh } \\
\text { Bolivia } \\
\text { Brazil } \\
\text { Cameroon } \\
\text { Central African Rep. } \\
\text { Chad } \\
\text { Congo, Republic } \\
\text { Cote d'Ivoire } \\
\text { Ecuador } \\
\text { Dominican Rep. } \\
\text { Egypt } \\
\text { El Salvador } \\
\text { Fiji } \\
\text { Gabon } \\
\text { Guatemala } \\
\text { Haiti } \\
\text { Honduras } \\
\text { Kenya } \\
\text { Madagascar } \\
\text { Malawi } \\
\text { Nicaragua } \\
\text { Mexico } \\
\text { Niger } \\
\text { Nigeria } \\
\text { Pakistan } \\
\text { Paraguay } \\
\text { Peru } \\
\text { Sierra Leone } \\
\text { Sudan } \\
\text { Togo } \\
\text { Zambia }\end{array}$ \\
\hline
\end{tabular}


Table 6: Countries by Religion

\begin{tabular}{|c|c|c|}
\hline Christian & Muslim & Others \\
\hline Argentina & Algeria & Benin \\
\hline Bolivia & Bangladesh & China \\
\hline Botswana & Burkina Faso & Cote d'Ivoire \\
\hline Brazil & Chad & India \\
\hline Cameroon & Egypt & Israel \\
\hline Central African Rep. & Gambia, The & Madagascar \\
\hline Chile & Indonesia & Mauritius \\
\hline Colombia & Jordan & Singapore \\
\hline Congo, Rep. & Malaysia & South Korea \\
\hline Costa Rica & Mali & Sri Lanka \\
\hline Dominica Rep. & Morocco & Thailand \\
\hline Ecuador & Niger & Togo \\
\hline El Salvador & Nigeria & \\
\hline Eswatini & Oman & \\
\hline Fiji & Pakistan & \\
\hline Gabon & Saudi Arabia & \\
\hline Ghana & Senegal & \\
\hline Guatemala & Sierra Leone & \\
\hline Guyana & Sudan & \\
\hline Haiti & Tunisia & \\
\hline Honduras & Turkey & \\
\hline \multicolumn{3}{|l|}{ Jamaica } \\
\hline \multicolumn{3}{|l|}{ Kenya } \\
\hline \multicolumn{3}{|l|}{ Malawi } \\
\hline \multicolumn{3}{|l|}{ Mexico } \\
\hline \multicolumn{3}{|l|}{ Nicaragua } \\
\hline \multicolumn{3}{|l|}{ Panama } \\
\hline \multicolumn{3}{|l|}{ Paraguay } \\
\hline \multicolumn{3}{|l|}{ Peru } \\
\hline \multicolumn{3}{|l|}{ Philippines } \\
\hline \multicolumn{3}{|l|}{ Rwanda } \\
\hline \multicolumn{3}{|l|}{ South Africa } \\
\hline \multicolumn{3}{|l|}{ Suriname } \\
\hline \multicolumn{3}{|l|}{ Trinidad and Tobago } \\
\hline Uruguay & & \\
\hline Zambia & & \\
\hline
\end{tabular}


Table 10: Correlation Matrix of Trade Openness

\begin{tabular}{|c|c|c|c|c|}
\hline VARIABLE & $\begin{array}{c}\text { Trade } \\
\text { Openness }\end{array}$ & $\begin{array}{c}\text { Trade } \\
\text { Openness }^{2}\end{array}$ & $\begin{array}{c}\text { Trade } \\
\text { Openness } \\
\text { (centered) }\end{array}$ & $\begin{array}{c}\text { Trade } \\
\text { Openness }^{2} \\
\text { (centered) }\end{array}$ \\
\hline Trade Openness & 1.0000 & & & \\
\hline Trade Openness $^{2}$ & 0.9157 & 1.0000 & & \\
\hline Trade Openness (centered) & 1.0000 & 0.9157 & 1.0000 & \\
\hline Trade Openness $^{2}$ (centered) & 0.7677 & 0.9605 & 0.7677 & 1.0000 \\
\hline
\end{tabular}

Table 12: Turning Points

\begin{tabular}{|l|c|c|}
\hline Variable & $\begin{array}{l}\text { Turning Point (Based on } \\
\text { Centered Variables) }\end{array}$ & $\begin{array}{l}\text { Turning Point (Rescaled to } \\
\text { Original Variables) }\end{array}$ \\
\hline Trade Openness & 283.2456 & 354.85226 \\
\hline Polity2 & n/a & 2.827122 \\
\hline Index of Political Stability & n/a & 24.17558 \\
\hline FINANCE & n/a & -1.700638 \\
\hline
\end{tabular}

n/a means not applicable 


\section{APPENDIX B (FIGURES)}

Figure 15: Means of Indices of Financial Development and Polity2

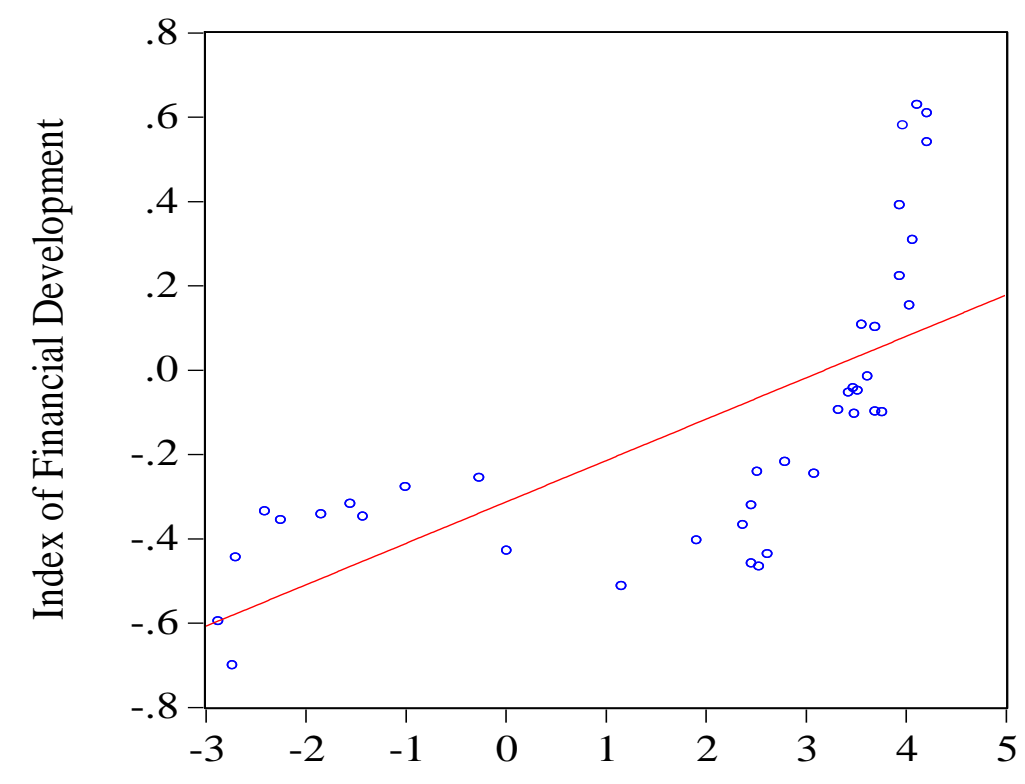

Index of Polity2

Figure 16: Predictive Margins with 95\% Cls

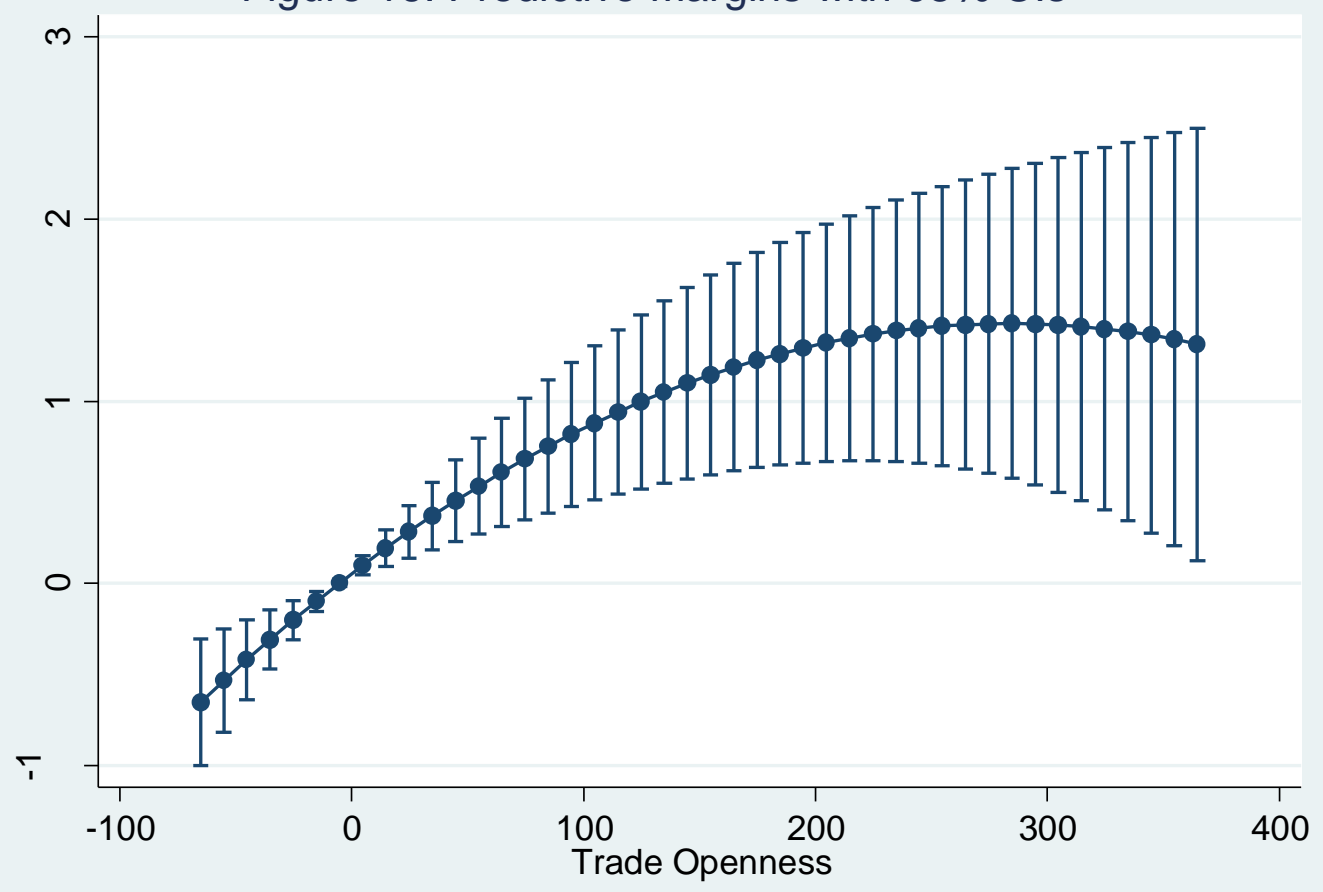


Figure 17: Predictive Margins with 95\% Cls

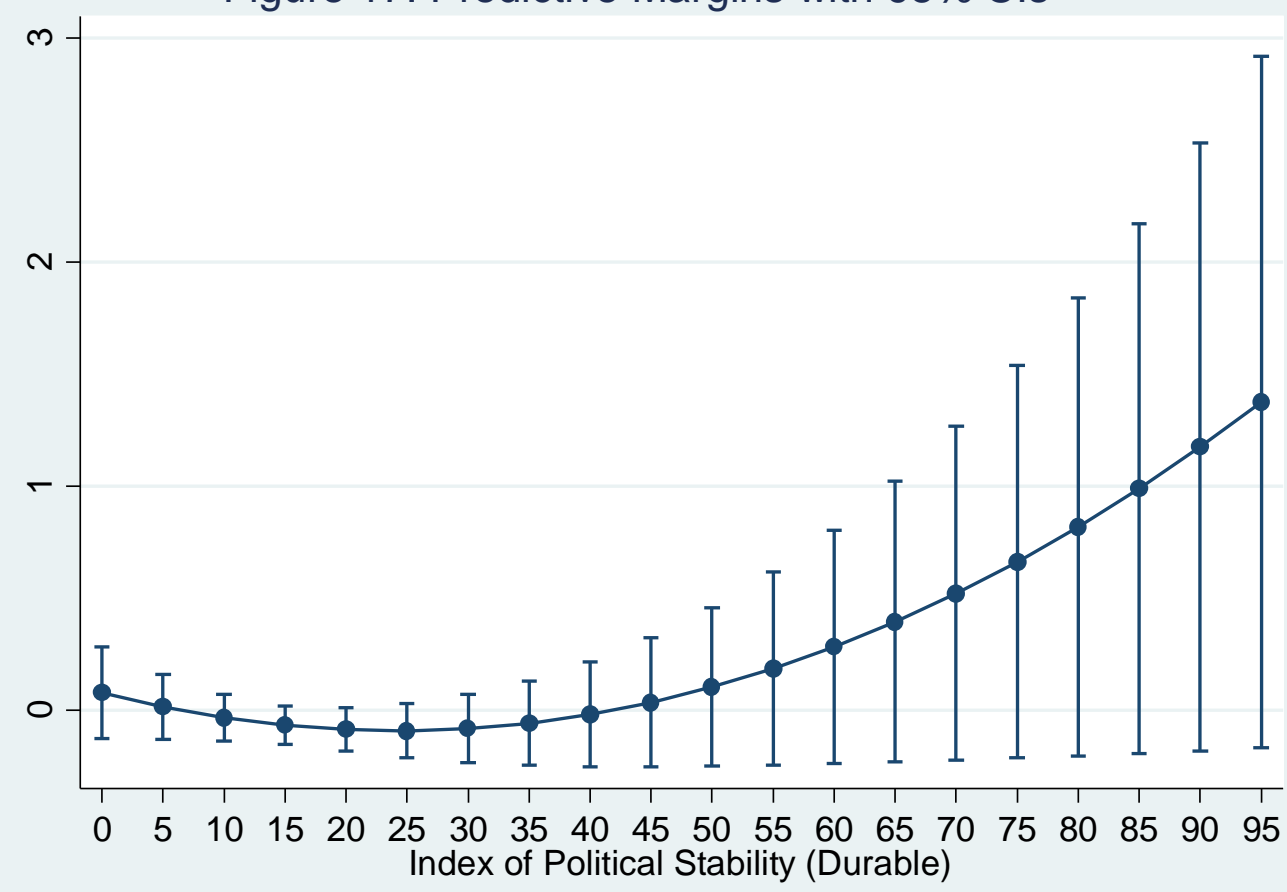

Figure 18: Predictive Margins with 95\% Cls

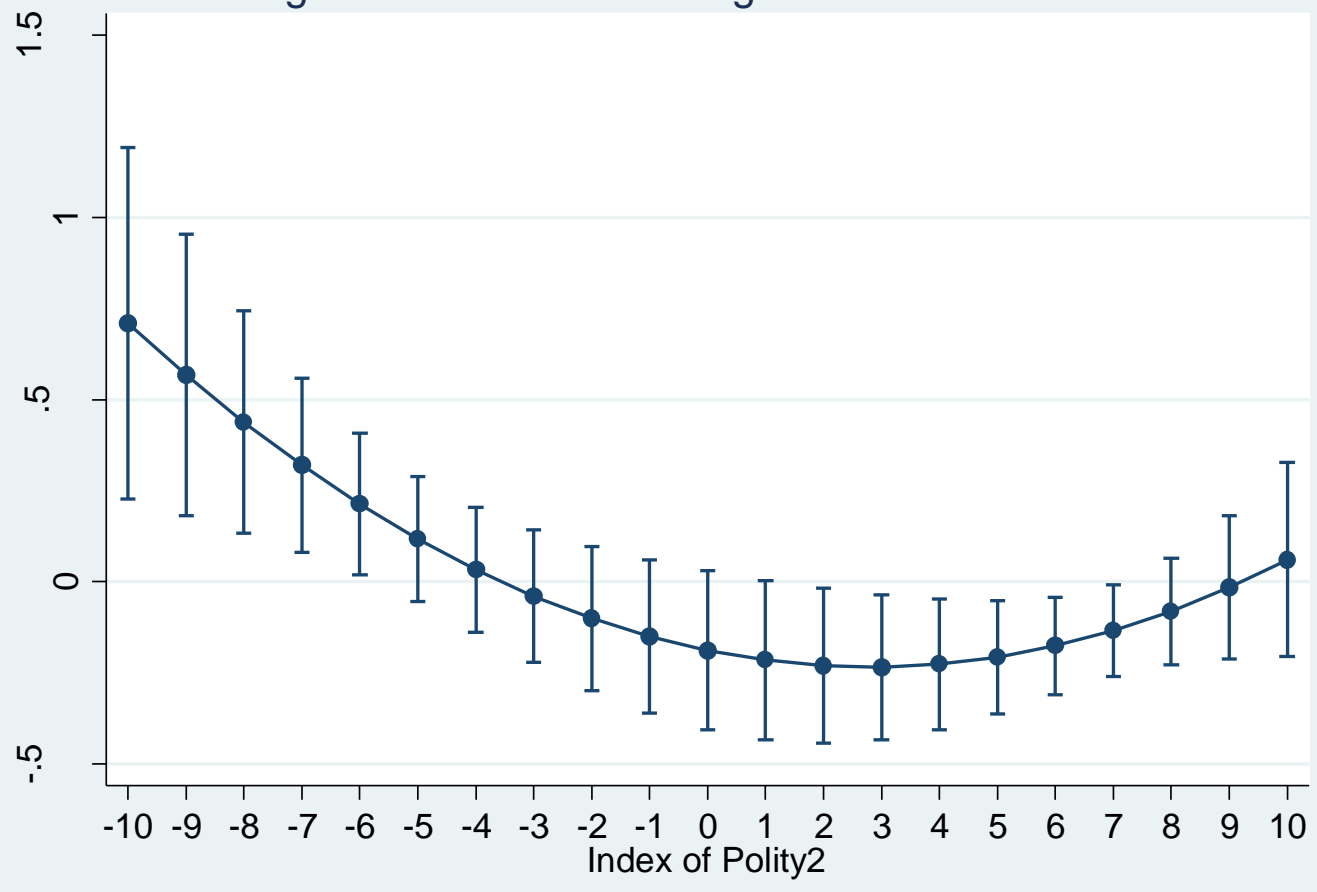


Figure 19: Predictive Margins with 95\% Cls

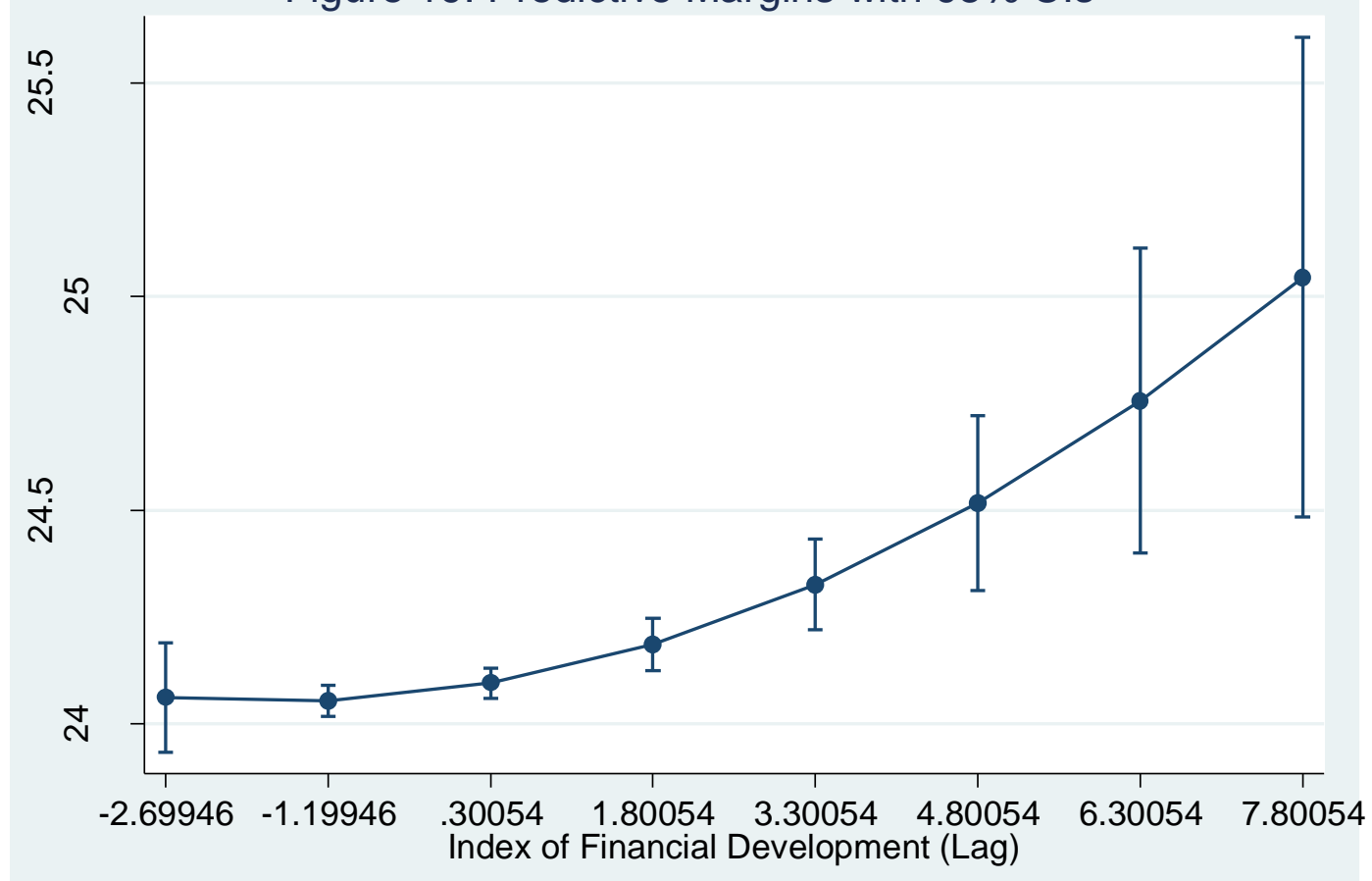

